\title{
Evaluation of Antibiotic Resistance and Biofilm Formation Ability Uropathogenic E. coli (UPEC) Isolated from Pregnant Women in Karaj
}

\author{
Maryam Nikzad $^{1}$, Reza Mirnejad² ${ }^{2}$, Ebrahim Babapour ${ }^{3 *}$ (D)
}

1. Department of Microbiology, Karaj Branch, Islamic Azad University, Karaj, Iran

2. Molecular Biology Research Center, Systems Biology and Poisonings Institute, Baqiyatallah University of Medical Sciences, Tehran, Iran

3. Department of Microbiology, Karaj Branch, Islamic Azad University, Karaj, Iran

\section{ABSTRACT}

Background and Aim: Uropathogenic Escherichia coli (UPEC) are the most common cause of urinary tract infections. The binding of these bacteria to epithelial cells and the formation of biofilms cause these bacteria to be further colonized and difficult to remove in the urinary tract. This study aimed to determine the antibiotic resistance and to evaluate the biofilm formation power in Escherichia coli isolated from pregnant women in the city of Karaj, Iran.

Materials and Methods: This descriptive-analytical study was performed on 64 isolates of UPEC. Identification of these bacteria was determined using biochemical tests and antibiotic resistance by Kirby - Bauer method and according to the recommendation of the Clinical and Laboratory Standards Institute (CLSI 2017) guideline. The ability to form biofilms, using the microtiter plate method and the presence of papC and sfa genes was examined by Duplex PCR.

Results: Based on the results; the highest levels of resistance were related to cotrimoxazole (40.6\%), and ampicillin (31.3\%). The examination of biofilm formation by the phenotypic method also showed that of the isolates, $48.4 \%$ (strongly), $15.6 \%$ (moderately) and $21.8 \%$ (weakly) have biofilm formation power. Based on the obtained Duplex PCR results, 15 isolates had papC gene, 10 isolates had sfa gene and 9 isolates had both genes simultaneously. $100 \%$ of the isolates with both papC and sfa genes were able to produce biofilms.

Conclusion: The results showed that most UPEC causing urinary tract infections can form biofilms. Also, the abundance of papC and sfa genes encoding pili in these strains can act as one of the binding factors of this bacterium.

Keywords: Antibiotic resistance, Biofilm formation, Duplex PCR, Uropathogenic Escherichia coli (UPEC)

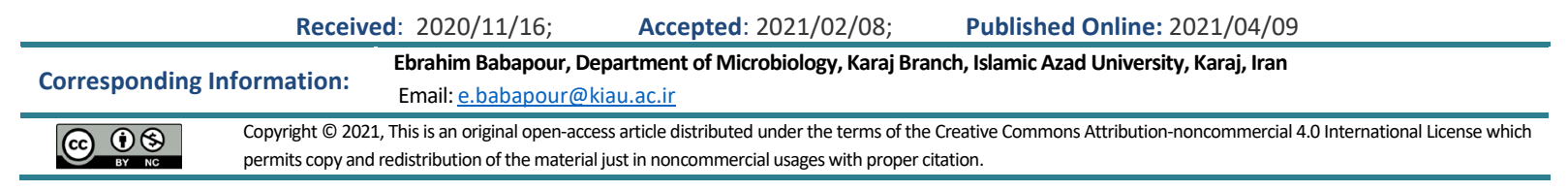

Use your device to scan and read the article online

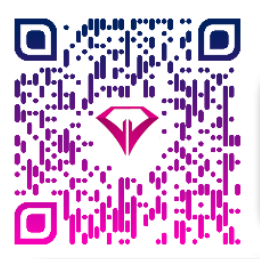

Nikzad M, Mirnejad R, Babapour E. Evaluation of Antibiotic Resistance and Biofilm Formation Ability Uropathogenic E. coli (UPEC) Isolated From Pregnant Women in Karaj. Iran J Med Microbiol. 2021; 15 (2) :195-211

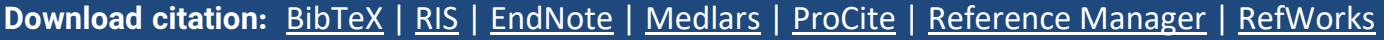

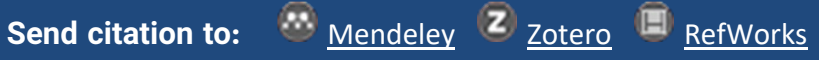

\section{Introduction}

Escherichia coli is the most common cause of urinary tract infections (UTI) in humans. Ecological status, ability to epithelial cell attachment, urinary lavage resistance, and biofilm formation are among the factors that make uropathogenic E. coli (UPEC) the leading cause of UTI in humans. This bacterium is an extremely diverse species that can colonize and persist in countless niches in animals, humans, and the environment (1). Some strains of $E$. coli can be distinguished from their common strains and cause more natural pathogenesis in the gastrointestinal tract, tissues, and other host organs. The diarrhea- 
causing $E$. coli are widely classified as extraintestinal pathogenic E. coli (ExPECs) (2). ExPECs strains are associated with human urinary tract infections. UPEC strains act as intracellular opportunistic pathogens and are superior to host sensitivity and behavior by using different virulence factors for colonization in the urinary tract $(1,2,3)$. UPEC strains can colonize the urinary tract and bladder and cause inflammation of the bladder, as well as the ureter and kidneys causing pyelonephritis. Cell surface molecules and various structures involved in biofilm formation of UPEC (3). Biofilms are a collection of microbial cells that are irreversibly surface-dependent and are not destroyed by gentle washing (4). Besides, the tendency of planktonic cells to reach the surface of the mature biofilm causes phenotypic changes that have major consequences such as increased resistance to antimicrobial agents and resistance to host defense (5). More than $50 \%$ of all reported bacterial infections make up the biofilm. Biofilm growth of pathogenic bacteria often leads to infections that increase antibiotic tolerance and host immune responses (6). Bacterial attachment to uroepithelial cells allows the bacterium to resist the function of emptying the bladder and activating the message pathways in the host. Therefore, the attachment of bacteria to uroepithelial cells is an important step in the onset and spread of urinary tract infections, because unlike other bacteria, these bacteria do not wash out quickly (7). This binding occurs through one of the bacterial adhesion's called P-fimbriae, which is encoded by the pap or pyelonephritis associated pili gene (7). Pfimbriae is involved in bacterial colonization of the upper urinary tract, attachment to the renal vascular endothelium, and ultimately pyelonephritis (7). Another important adhesin factor in this regard is $\mathrm{S}$ fimbriae, which is encoded by the $s f a$ or S-fimbrial adhesion gene. The above genes are of the mannoseresistant adenosine type and are located on an area of the chromosome called the Pathogenicity Islands (8). The pap and sfa genes are the most common genes encoding pili in E. coli isolated from UTI that can help bacterial attachment to the host tissues and form antibiotic-resistant biofilms. Identification of biofilmproducing UPEC strains is important to better understand the pathogenicity and antibiotic resistance of this bacterium in UTI (9). On the other hand, determining the antibiotic resistance pattern of E. coli causing UTI in the country, to identify drugs effective in the initial treatment of UTI and emerging resistance, can be very effective in controlling the disease. Therefore, this study aimed to determine the antibiotic resistance pattern of $E$. coli causing UTI, evaluate the biofilm formation using the microtiter plate method, and investigate $p a p C$ and sfa fimbriae genes using the Duplex PCR method.

\section{Materials and Methods}

\section{Collection, Isolation, and Identification}

In this descriptive-analytical study, during 3 months (from February to May 2017), 100 urine samples from pregnant women suspected of UTI were collected from comprehensive health centers in Karaj, Iran. To isolate E. coli and ensure the purity of the samples, each sample was cultured on McConkey agar and nutrient agar medium, and the presence of E. coli was confirmed by routine microscopic and biochemical tests.

Determination of Antibiotic Susceptibility by Disk Diffusion Method

Kirby-Bauer disk diffusion method was performed to determine the antibiotic susceptibility of $E$. coli isolates against six different antibiotic classes in Mueller-Hinton agar (Merck, Germany) according to the CLSI recommendations (2017). The antibiotic disks included ampicillin (AM, 10 $\mathrm{g}$ ), cotrimoxazole (SXT,

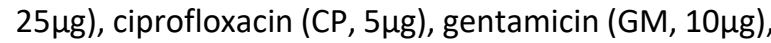

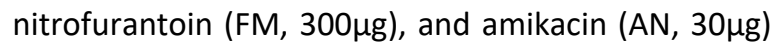
(Padtan Teb Co, Iran). Reference strains of E. coli ATCC 25922 were used as quality control of the antibiotic disks (10).

\section{Evaluation of Biofilm Formation in UPEC by Microtiter Plate Method}

In this method, a 24-hour culture of bacteria in Luria Bertani (LB) liquid medium was dilute as 0.5 McFarland turbidity and pour $10 \mu \mathrm{L}$ into $990 \mu \mathrm{L}$ of sterile LB medium to prepare a $1 \%$ dilution and then $200 \mu \mathrm{L}$ was added to three cavities of the plate. After 24 hours of incubation at $37^{\circ} \mathrm{C}$, first, it was washed with saline phosphate buffer three times at $\mathrm{pH} 7.3$ to remove the bacteria that are not connected to the plate wall. It is then fixed with $250 \mu \mathrm{L}$ of pure methanol for 15 minutes. Then, $200 \mu \mathrm{L}$ crystal violet staining $2 \%$ was added and after 5 minutes, it was washed with phosphate-buffered saline. After that, $160 \mu \mathrm{L}$ of glacial acetic acid 33\% v / v was added to every well, after 15 minutes of incubation of the plates at $37^{\circ} \mathrm{C}$, the light absorption of stained wells was detected with a wavelength of $570 \mathrm{~nm}$ in the ELISA reader (Stat Fax - 4200).

The results were divided according to Table 1, without the ability to form biofilms $(-)$, weak $(+)$, medium (++), and high strength (+++). To increase the accuracy of the experiment, each sample was repeated three times and the average obtained was considered as the final result of the experiment (4).

\section{DNA Extraction for Duplex PCR}

The boiling method was used to extract the DNA content of bacterial isolates (4). After extracting the DNA, evaluated qualitatively and quantitatively using 
a spectrophotometer, and electrophoresis was carried out on $1 \%$ agarose gel. The extracted DNA was stored at $-70^{\circ} \mathrm{C}$ until further analysis.

\section{Duplex PCR Reaction for the Detection of papC and $s f a$ Genes}

Amplification reactions were carried out in $25 \mu \mathrm{L}$ volumes comprising; one microliter of target DNA (10 $\mathrm{ng} / \mu \mathrm{L}$ ), $12.5 \mu \mathrm{L}$ of dye Master mix2X (CinaGen, Co., Tehran, Iran), $1 \mu \mathrm{L}$ of each Forward and Revers primers $(20 \mathrm{p} / \mathrm{mol})$ (Forward primers for papC $\mathrm{F} 5$ GACGGCTGTACTGCAGGGTGTGGCG-3 and Revers PapC R 5- ATATCCTTTCTGCAGgGATGCAATA-3 and Forward primers for sfa $\mathrm{F}$ 5CTCCGGAGAACTGGGTGCATCTTAC-3 and Revers primers $s f a$ R 5- CGGAGGAGTAATTACAAACCTGGCA-3) and $9.5 \mu \mathrm{L}$ double distilled water.

Each program includes 30 cycles of PCR amplification under the following conditions: Initial denaturation at $94^{\circ} \mathrm{C}$ for 3 minutes, 30 thermal cycles including denaturation at $94^{\circ} \mathrm{C}$ for 1 minute, annealing at $59^{\circ} \mathrm{C}$ for 45 seconds, extension at $72^{\circ} \mathrm{C}$ for 1 minute and final extension it was $72^{\circ} \mathrm{C}$ for 5 minutes. The amplified products were visualized after electrophoresis on a $1 \%$ agarose gel and finally evaluated with a UV transilluminator. In the PCR test, distilled water was used as a negative control and the reference strain of E. coli ATCC 10536 was used as a positive control.

\section{Statistical Analysis}

The results were evaluated by Excel 2010 (Microsoft Office, Microsoft, Washington D.C, USA) and SPSS 2016 (SPSS Inc., Chicago, IL, USA) and the nonindependence test in inferential statistics to investigate the relationship between qualitative variables. P-value $\leq 0.05$ was analyzed as the significance level.

\section{Results}

\section{Collection, Isolation, and Identification}

Based on microscopic and biochemical tests, E. coli was isolated from 64 (64\%) samples obtained from patients suspected of UTI.

\section{Antibiotic Susceptibility Test}

The results of the antibiogram test showed that out of 64 isolates, 20 (31\%), 26 (40\%), 8 (12.52\%), $5(8.7 \%)$, $3(4.6 \%)$ and $2(3.1 \%)$ isolates were resistant to ampicillin (AM), trimethoprim-sulfamethoxazole
(SXT), ciprofloxacin (CP), gentamicin, nitrofurantoin (FM), and amikacin (AN), respectively (Table 2).

\section{Biofilm Formation by Microtiter Plate Method}

The results of the study showed that out of 64 isolates studied, 31 isolates (48.4\%) with high power, 10 isolates (15.6\%) with moderate power and 14 isolates $(21.8 \%)$ had biofilm formation capacity as a weak and only 9 isolates (14.2\%) lacked biofilm production capacity. In other words, $85.8 \%$ of total isolates had the ability to biofilm formation. The results showed that there was high antibiotic resistance among bacteria with a high and moderate capacity of biofilm formation in comparison to bacteria with weak or without biofilms formation, however, no significant association was observed between antibiotic resistance and biofilm formation

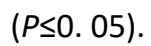

\section{Detection of papC and sfa Genes in UPEC Isolates by Duplex PCR}

Detection of papC and sfa genes was performed using the Duplex PCR technique. Duplex PCR reaction on DNA extracted from $E$. coli isolated in this study showed that 15 isolates (23.44\%) had papC gene and 10 isolates (15.62\%) had $s f a$ gene and 9 isolates (14.06\%) have both sfa and papC genes, simultaneously (Figure 1). Also, out of $15 \mathrm{E}$. coli isolates that had papC gene, 14 isolates (93.3\%) had the ability to biofilms formation and out of $10 \mathrm{E}$. coli isolates that had sfa gene, all (100\%) could produce biofilms, and all nine strains containing both genes could produce biofilms as well. The results of this study showed that the papC gene is more abundant among the isolates studied. The presence of papC and $s f a$ genes in these bacteria and their ability to produce biofilms are shown in Table 3. Examination of the results on the relationship between the presence of papC gene and the ability to form biofilms showed that the P-value $=0.36$, which is higher than $5 \%$, indicating no significant relationship between the presence of papC gene and biofilm formation, but given that Cramér's $V$ coefficient is 0.224 , indicating that there is a weak correlation between the variables. Regarding the relationship between the presence of the sfa gene and the ability to form biofilms, the $P$ value was $=0.624$, which is higher than $5 \%$, indicating a lack of a significant relationship between the presence of the sfa gene and biofilm formation, but considering that here too, Cramér's $V$ coefficient was 0.166 ; it showed that there is a weak correlation between the variables. 


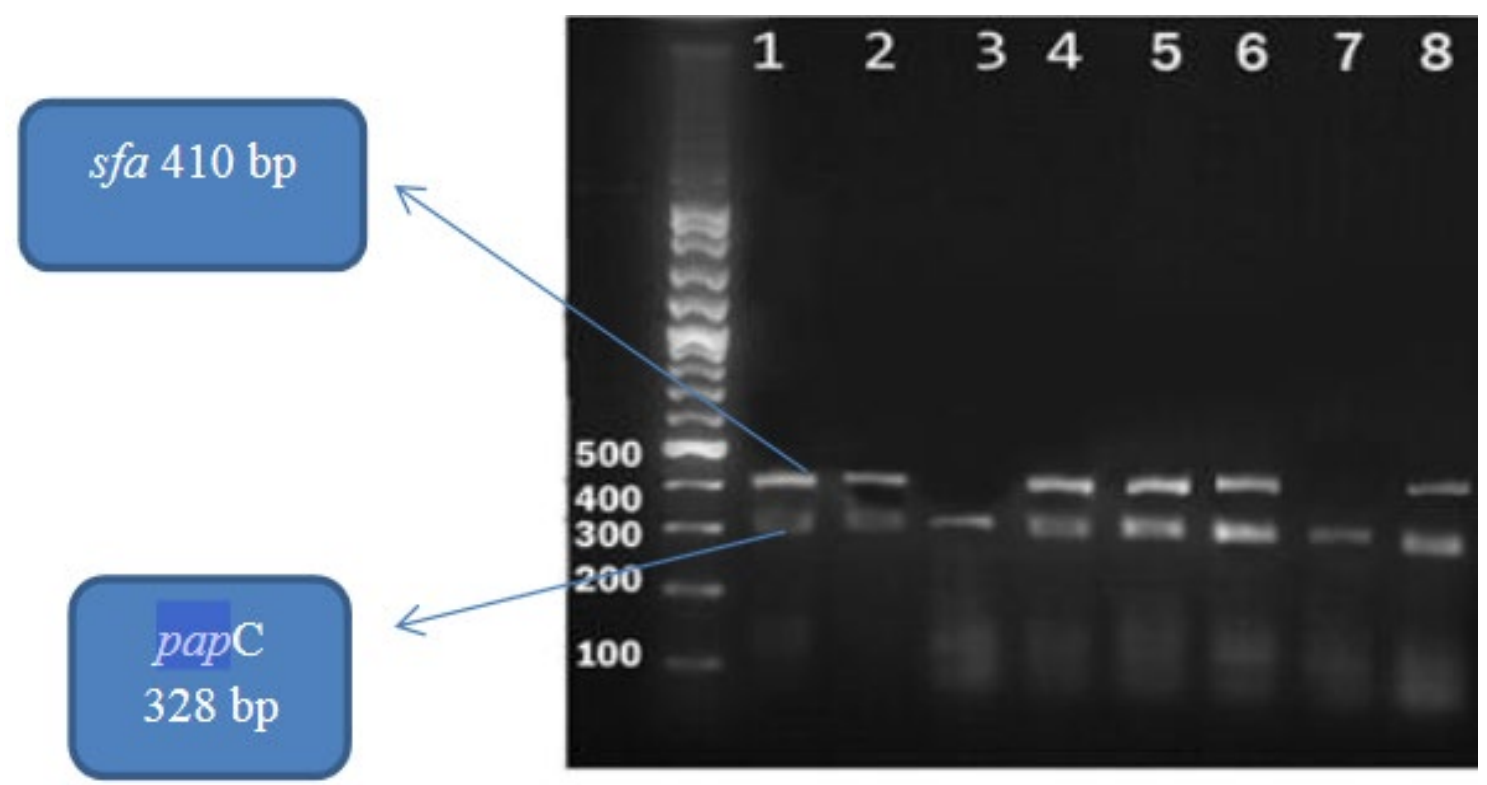

Figure 1. The results of electrophoresis of PCR products to identify genes papC (328 bp) and sfa (410 bp), wells $1,2,4,5,6$, and 8 are positive for both genes papC ( $328 \mathrm{bp})$ and $s f a(410 \mathrm{bp})$, and wells 3 and 7 are positive only for papC ( $328 \mathrm{bp})$.

\section{Discussion}

Uropathogenic $E$. coli pathotypes are responsible for $70-90 \%$ of community-acquired UTI and $50 \%$ of hospital-acquired UTI (12). UPEC damages the host tissue by colonization and biofilm formation in the mucosal epithelium. The attachment of urogenital bacteria to the epithelial cells is usually very important for biofilm formation because these bacteria do not wash out as quickly as other bacteria (13). This bacterium can form intercellular aggregates similar to biofilm structures within the bladder epithelium; therefore, biofilm formation plays an important role in the pathogenesis of UPEC (9). The papC and sfa genes are the most common genes encoding pili in $E$. coli isolated from UTI that can help bind the bacterium to host tissues and form antibiotic-resistant biofilms. Identification of biofilm-producing UPEC strains is important to better understand the pathogenicity and antibiotic resistance of this bacterium in UTI. On the other hand, determining the antibiotic resistance pattern of $E$. coli causing UTI to identify effective drugs in the initial treatment of disease and the emergence of resistance can be important in controlling urinary tract infections. In different parts of Iran, several studies have been performed on $E$. coli strains isolated from UTI (9); however, the overall results on the significant and pervasive resistances or emerging resistances of $E$. coli are not available in the country. Also, the trend of changing the pattern of antibiotic susceptibility of this main pathogen of the urinary tract in the country is not known. Considering the aforementioned points, the study was done on 100 samples of urine collected from pregnant women suspected of UTI, with ages between 20 and 25 years. Based on the results, E. coli was isolated from 64 (64\%) samples obtained from patients suspected of UTI. These results show that $E$. coli is still the most common cause of urinary tract infections. In this study, the resistance of UPEC bacteria causing UTI to antibiotics was investigated. Based on the results; the highest levels of resistance were related to cotrimoxazole (40.6\%), ampicillin (31.3\%), ciprofloxacin (12.5\%), gentamicin (7.8\%), nitrofurantoin (4.6\%), and amikacin (3.1\%), respectively, which is consistent with the results of a study conducted by Mattai et al. in 2004 (14). E. coli isolated in this study showed the highest sensitivity to amikacin (96.9\%), which is consistent with the study of Abdollahi Kheirabadi et al., in 2012, who reported the sensitivity of $E$. coli isolated from urinary specimens to amikacin (98\%) (15). Also, in a study conducted by Milani et al., on the antibiotic susceptibility of bacteria isolated from people with UTI, the highest resistance was to ampicillin (95.3\%) and the lowest resistance was to amikacin (6.6\%) (16). According to the results of this study, the level of resistance to ampicillin was higher than our findings, but in our study, most of the isolates were sensitive to amikacin. The results of the present study showed that more than $47 \%$ of the isolates were resistant to more than two groups of antibiotics. In a study conducted by Eslami et al. in Iran in 1995, 85.5\% of isolates showed resistance to more than two antibiotics (17). In a study by Molina_Lopez et al., (2011) in Mexico City, multidrug resistance strains of UPEC showed similar results (18). In their study, the lowest resistance was to amikacin and nitrofurantoin, which is consistent with the results of the present study (18). In the study of Mansouri et al., the resistance to ciprofloxacin was $41 \%$, gentamicin was 
$34.8 \%$ and cotrimoxazole was $93.5 \%$, which has a higher resistance compared to the present study (19); this may be due to differences in geographical areas and sources from which the bacterium has been isolated. One of the factors that play a role in pathogenesis as well as resistance to antimicrobial agents is the potential of biofilm formation. The first step in the process of colonization or infection is the attachment of bacteria to the host cell. In this study, the strength of biofilm formation was investigated by the microtiter plate method, which is a standard qualitative method (4).

In this study, $48.4 \%$ of the isolates were strong biofilm producers, $15.6 \%$ were moderately potent, $21.8 \%$ were weak and $14.2 \%$ were not biofilm producers. In the study of Sevanan et al. in 2011, they used the biofilm formation method in the tube (Tube Method) and showed that $9.4 \%$ of the isolates were high strength biofilm producer, $34.4 \%$ of the isolates were moderately potent, and $40.6 \%$ of the isolates with weak power could produce biofilm and $15.6 \%$ could not produce biofilm; These results showed more biofilm formation compared to microtiter plate method (20). Rawa'a Al-Chalabi et al. also reported in 2010 that $90 \%$ of UPEC strains can form biofilms (21). In a 2012 study by Ponnusamy et al., out of 100 strains of UPEC, 72 strains showed positive biofilm phenotypes, of which $17 \%$ were high strength, $19 \%$ were moderately potent, and $36 \%$ of the isolates were with weak power (22). In a study conducted by Katongole et al. in 2020 on 200 UPEC isolates, biofilm production was reported to be $62.5 \%(23)$. The results of this study show a slight difference compared to our study, which could be due to the type of method used to measure the biofilm and differences in the sources of the sample.

In this study, the Duplex PCR method was used to evaluate the presence of papC and sfa genes in UPEC isolates. The results showed, 15 isolates (23.4\%) carried the papC gene and 10 isolates $(15.6 \%)$ had the sfa gene and 9 isolates (14.06\%) have both sfa and papC genes, simultaneously. In a study by Katongole et al., $22 \%$ and $13 \%$ of papC and sfa genes were reported, respectively (23). In the study of Tarchouna et al., the frequency of papC was $41 \%$ and the frequency of the $s f a / f o c$ gene was 34\% (24). In a study conducted by López-Banda et al. in Mexico on 108 E. coli isolated from women with UTI, pathogenic genes, and drug resistance were examined in phylogenetic groups, and the frequency of sfaS and papC was reported to be $1.9 \%$ and $62 \%$, respectively (25). In a study conducted by Najafi et al. in 2017 in Bushehr, Iran, on 140 UPEC isolates, the frequency of the papC gene was $38.6 \%$ and the frequency of the sfa / foc gene was $0.7 \%(26)$. The prevalence of the papC gene was 53.3\% in a study by Asadi et al., in 2014 (27). In a study by Abe et al., in $225 \mathrm{E}$. coli in Brazil, they determined the frequency of pap and sfa genes to be $45.8 \%$ and $29.8 \%$, respectively (28). A 2008 study by Grude et al. on 30 fluoroquinolone-resistant UPEC in Norway found that the frequency of pap and sfa genes was $27 \%$ and $0 \%$, respectively (29). In the study of Tiba et al., which was performed in 2008 on 162 UPEC isolates in Brazil, the frequencies of pap, afa, and $s f a$ genes were reported to be $32.7 \%, 27.8 \%$, and $6.2 \%$, respectively (30). In 2006, Arisoy et al. determined the frequency of pap and sfa genes to be $22.98 \%$ and $6.21 \%$, respectively, by examining 161 UPEC isolates (31). In another study performed by Fathollahi et al. on $E$. coli, isolated from various forms of UTI, the prevalence of pap operon was reported (32). Out of 123 E. coli isolates collected from UTI by Karimian et al., $27 \%$ had pap gene and $14.6 \%$ had sfa gene (33). In Bahalo et al. study, the frequency of the pap gene was $40 \%$ and the sfa gene was $30 \%$ (34). On the other hand, in the report of Mohajeri et al., the frequency of the pap gene was $20.5 \%$ and the frequency of the $s f a$ gene was $21.5 \%$ (35). As shown in the results of various studies, in almost all of them, the amount of pap gene is higher than sfa gene, which is consistent with the results of our research, but there is also a difference in the mentioned percentages, which may be due to differences in the number of isolates, type of samples, location of collection, the type of primer and even the protocol used for PCR. In a 2018 study by Zamani et al. on UPEC, the relationship between biofilm formation potential and genes involved in the attachment was evaluated and it was reported that there is a moderate to a strong relationship between sfaS and biofilm formation ability in biofilm-producing isolates (36). However, no significant relationship was observed between the presence of the papC gene and the ability to biofilm formation (36). Also, in the study of Katongole et al., it was found that $50 \%$ of isolates containing the papc gene were able to biofilm formation, but $53.8 \%$ of isolates containing the $s f a$ gene were able to produce biofilms (23). The results of the present study also showed that 14 isolates (93.3\%) that had the papC gene, and all (100\%) isolates that had sfa gene, could produce biofilms. Also, all 9 isolates that had both studied genes simultaneously could produce biofilms. However, the results indicate the role of these genes in biofilm formation; the statistical study showed that up to the level of P-value $\leq 0.05$, there was no significant relationship between antibiotic resistance and biofilm formation, as well as between the ability to form biofilm and having papC and $s f a$ genes because there were many isolates biofilms lacked the above genes, or although antibiotic resistance was higher among isolates capable of biofilm, a significant number were sensitive to the antibiotics studied despite their ability to produce biofilms. This confirms that; although biofilm 
production increases antibiotic resistance in bacteria, drug resistance does not depend only on the presence of biofilm and many other factors such as the presence of degrading enzymes, the presence of effusion pumps, changes in the site of action, etc. also play a role in resistance. However, having fimbriae are effective in biofilm formation, but in addition to fimbriae, numerous other factors in bacteria (including the presence of capsules and surface proteins, etc.) are effective in biofilm formation, and these results are consistent with the results of other studies $(1,4,6,7,8,20,22)$.

\section{Conclusion}

According to the results of this study, UPEC is still the main cause of UTI and can produce a biofilm and the binding power of this bacterium in this field has an irreversible role. On the other hand, the ability to create biofilms in $100 \%$ of isolates that have papC and sfa genes encoding fimbriae shows that fimbriae can play an effective role in this feature. The results also showed that there is a direct relationship between biofilm formation power and increased drug resistance in UPEC bacteria; Therefore, determining the pattern of $E$. coli antibiotic resistance in isolates obtained from UTI nationwide is very important in identifying effective drugs in the prevention and initial treatment of UTI.

\section{Acknowledgment}

This research paper is taken from the student dissertation of Master of Microbiology. The authors of this article would like to express their gratitude to the dean of the Faculty of Science and the experts of the Microbiology Research Laboratory of the Islamic Azad University, Karaj Branch.

\section{Funds}

This research has been done at personal expense and with the help and assistance of Islamic Azad University, Karaj Branch, and in the form of a master's thesis.

\section{Conflict of Interest}

There is no conflict of interest between the authors of the article. All authors endorsed the final manuscript. 


$$
\begin{aligned}
& \text { مجله ميكروبشناسى يزشكى ايران } \\
& \text { سال ه| _ شماره Y _ فروردين و ارديبهشت .. } \\
& \text { Journal homepage: www.ijmm.ir }
\end{aligned}
$$

\title{
بررسى مقاومت آنتىبيوتيكى و توانايى تشكيل بيوفيلم در
}

\section{اشريشيا كلى يوروياتوزن جداسازى شده از زنان باردار در شهر كرج}

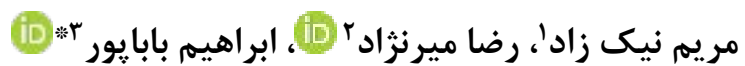

\begin{abstract}
'. . كارشناسى ارشد رشته ميكروبيولوزى، كروه ميكروبيولوزى، واحد كرج، دانشَاه آزاد اسلامى، كرج، ايران

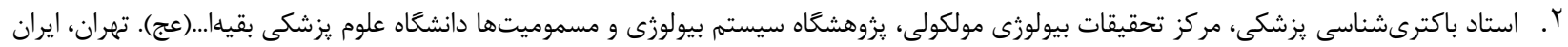

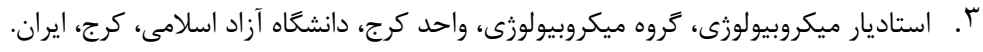

\section{جكيله}

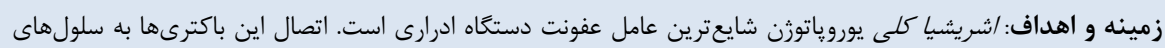

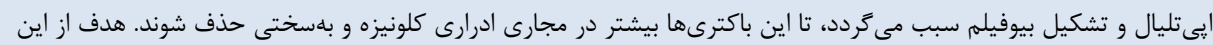

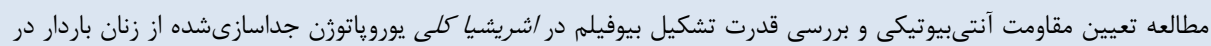

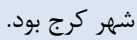

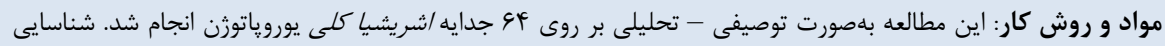

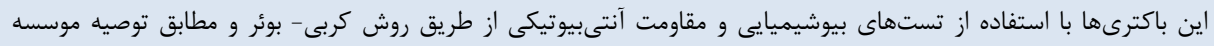

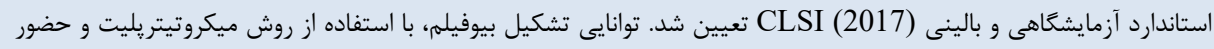

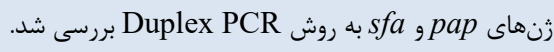

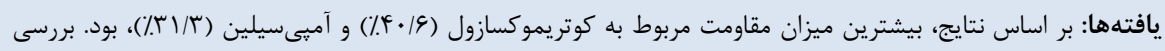

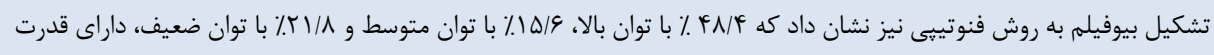

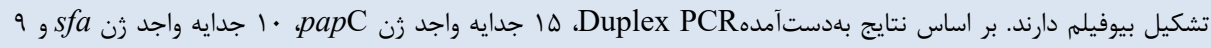

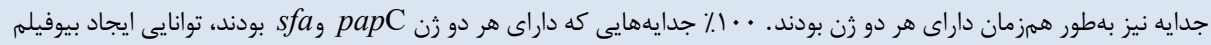
را داشتند.

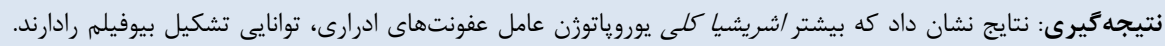

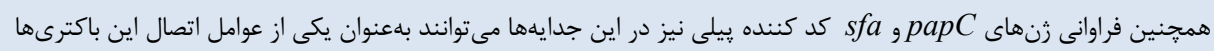

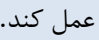

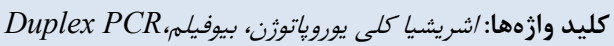

كيحرايت (؟ مجله ميكروب شناسى يزشكى ايران: دسترسى آزادك كبى بردارى، توزيع و نشر براى استفاده غيرتجارى با ذكر منع آزاد است.
|طلاعات مقاله

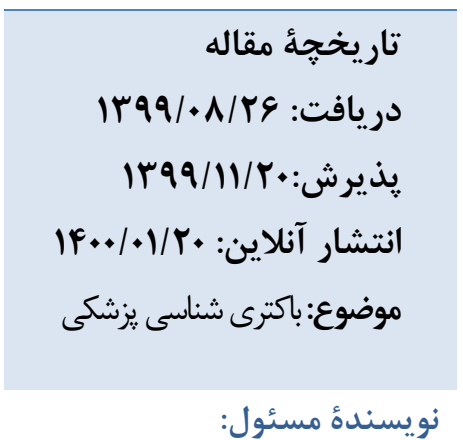

ابراهيم بابايور ، استاديار ميكروبيولوزى،

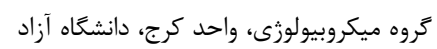
اسلامى، كرج، ايران

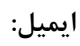
e.babapour@kiau.ac.ir
ديكر ميزبان ايجاد كنند. اين سويههاى ياتوزن بهطور كسترده

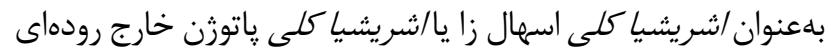
(Extra-intestinal Pathogenic E.coli)

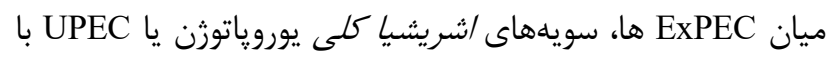

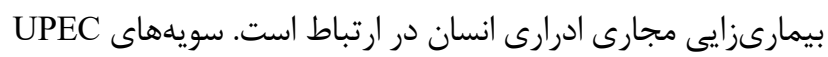

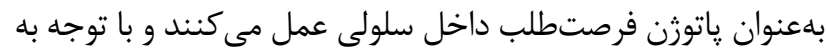
حساسيت و رفتار ميزبان و توسط بهكار كيرى فاكتورهاى ويرولانس

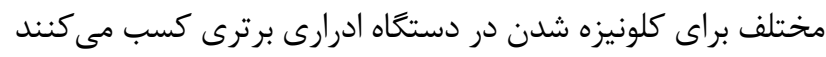
UPEC مى Uوانند در مجارى ادرارى و در مثانه

مقدمه

اشريشيا كلى، شايعترين عامل عفونتهاى ادرارى در انسان

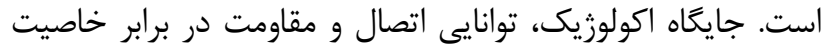

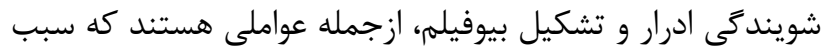

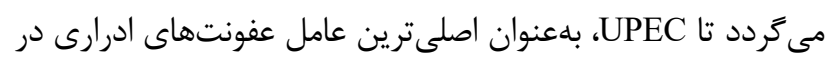

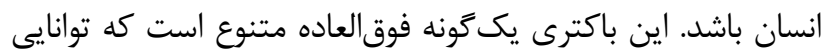
كلونيزه شدن و يايدارى در نيجهاى بىشمارى در ميزبانهاى يان

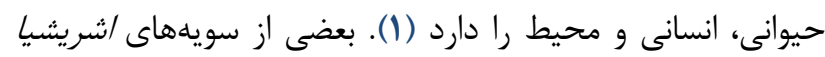

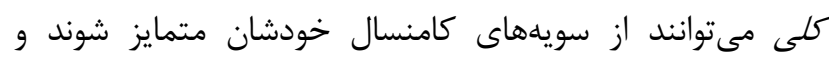

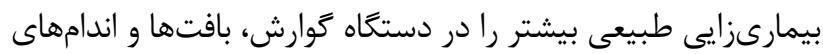


مؤثر در درمان اوليه عفونتهاى ادرارى و ايجاد مقاومتهاى نوظهور

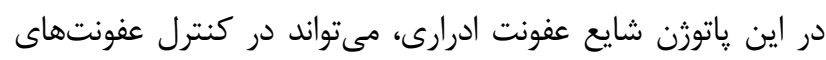

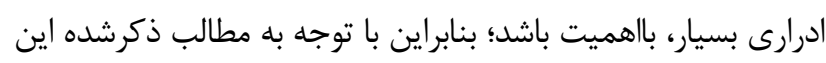

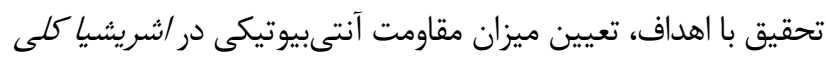

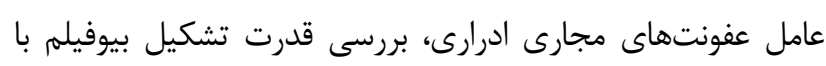

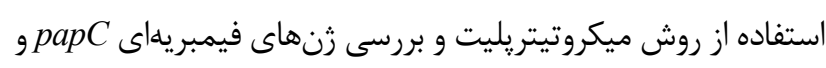

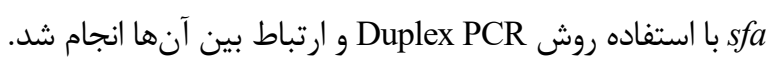

\section{مواد و روشها}

اين مطالعه باصورت توصيفى - تحليلى بر روى + . ا نمونه از

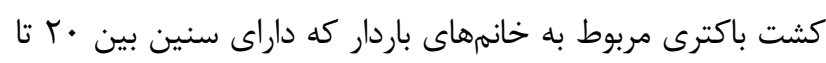

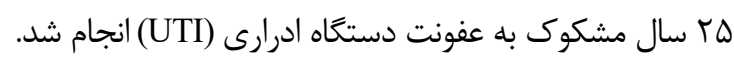

\section{جمع آورى، جداسازى و شناسايى:}

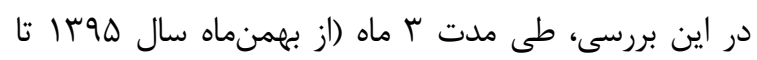

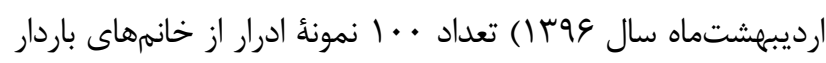

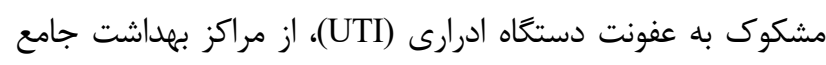

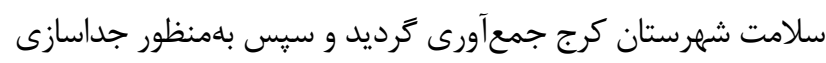

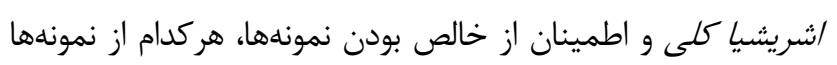

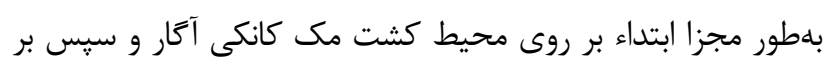

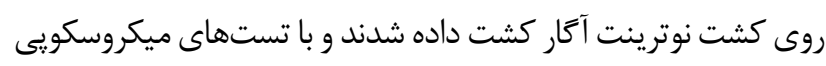
و بيوشيميايى متداول حضور باكترى/شريشيا كلى تائيد شد.

\section{تعيين حساسيت آنتىبيوتيكى به روش ديسك ديفيوزن}

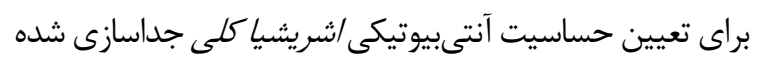

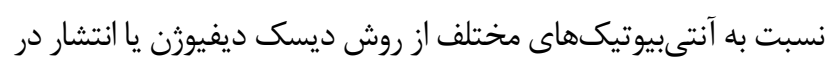
آكار به روش كربى- بوئر و مطابق با توصيه موسسه استاندارد

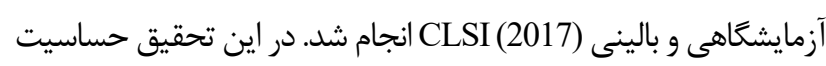

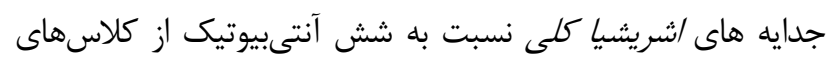

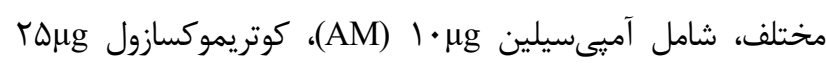

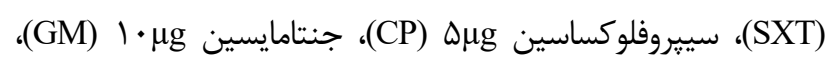

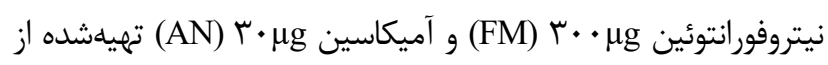

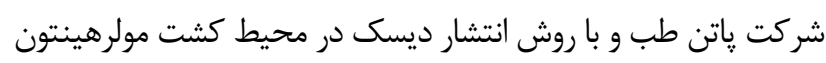
آكار (مرك المان) و بر اساس دستورالعمل (2017) CLSI انجام كَرديد؛ و از سويهى رفرنس /شريشيا كلى

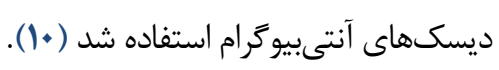

\section{بر رسى تشكيل بيوفيلم UPEC با روش ميكروتيتر يليت}

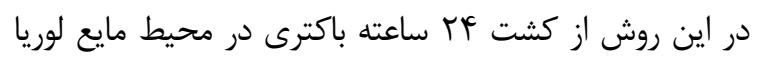

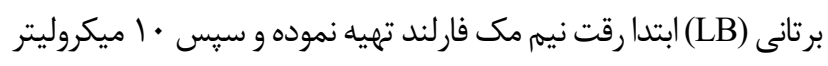

كلونيزه شده و ايجاد التهاب مثانه كنند و همجنين از طريق حالب

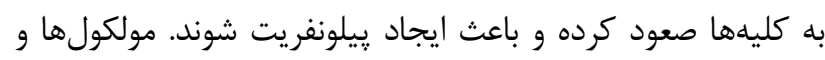
ساختارهاى مختلف سطح سلولى در تشكيل بيوفيله در /شريشيا كلى يوروياتوزن دخيل هستند (ب). بيوفيلم ها مجموعهاى از سلولهاى ميكروبى هستند كه بلهطور

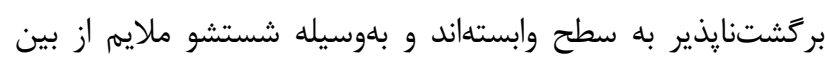

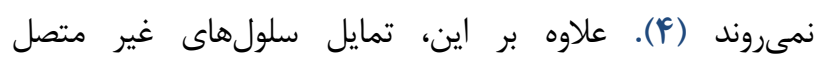

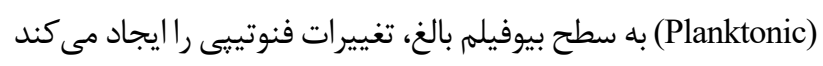

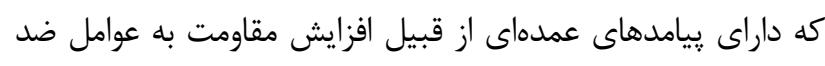

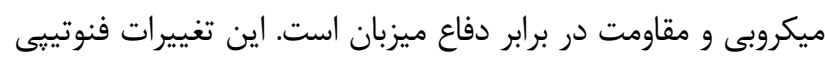

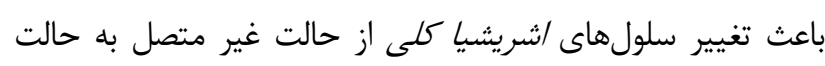

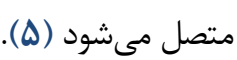

بيش از • ها٪ همه عفونتهاى باكتريايى تزارششده بيوفيلم

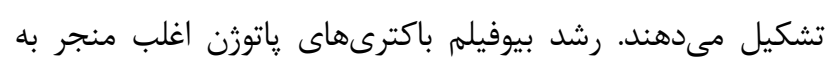

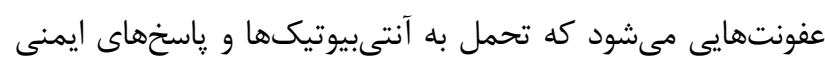
ميزبان را افزايش مى دهند (9). اتصال باكترى به سلولهاى يورو ايىتليال به باكترى اجازه مى دهد

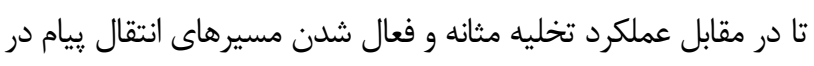

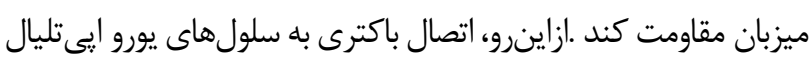

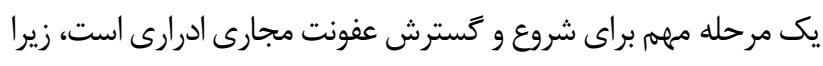

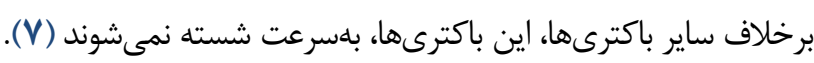

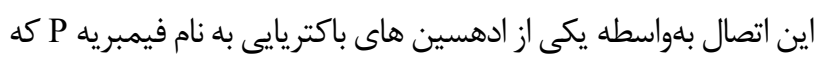

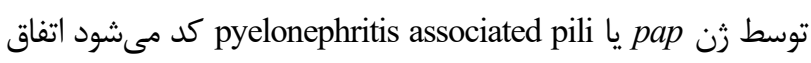

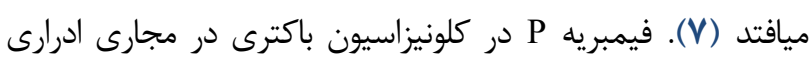

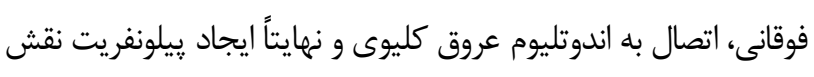

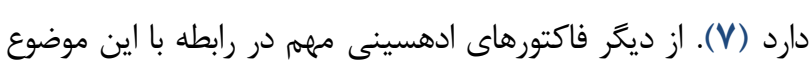

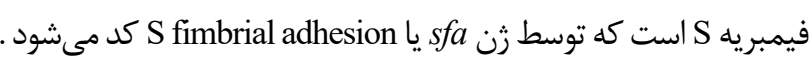
زن هاى فوق از نوع ادهسين هاى مقاوم به مانوز بوده و بر بر روى ناحيط ناحيداى

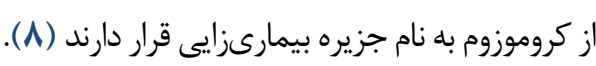
زنهاى pap و sfa شايعترين زنهاى كد كننده يِلى در

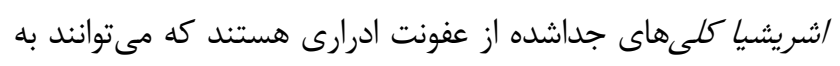

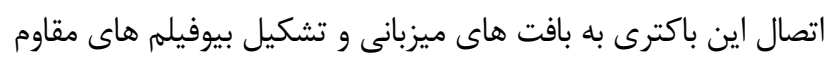

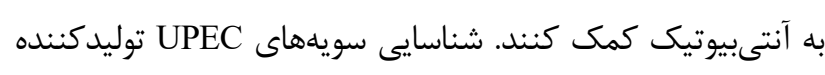
بيوفيلم براى درى بهتر بيمارىزايى و مقاومت آنتىبيوتيكى اين كمين

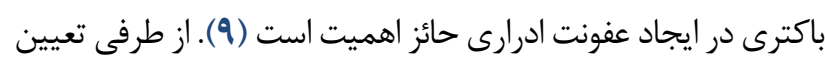

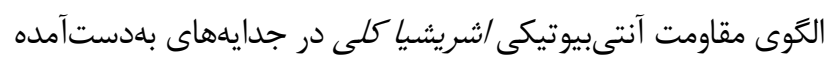

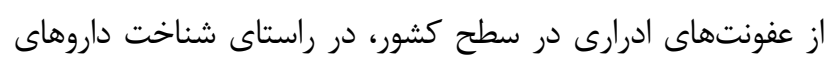


گرفت و سيس با •19 ميكروليتر اسيد استيك كلايسيال سبر٪ حجمى/حجمى باعنوان حلال يركرده، بعد از ها دقيقه انكوباسيون

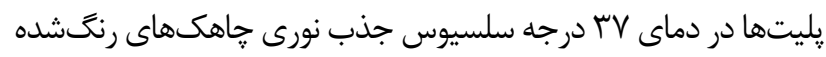
با كريستال ويوله، با طولموج • نV نانومتر در دستخاه اليزا ريدر ( Fax - 4200)

نتايج بر اساس جدول شماره (1) بهصورت فاقد قدرت تشكيل

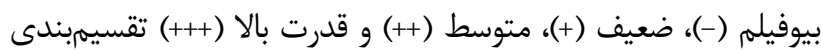
گرديد. براى بالا بردن دقت آزمايش هر نمونه سه مرتبه تكرار و متوسط

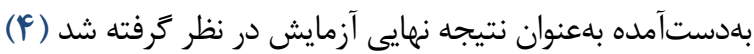

از آن را به •99 ميكروليتر از محيط ليتر لوريا برتانى (LB) استريل

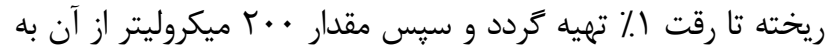
سه حفره از يليت مخصوص كشت بافت ته صاف اضافه شد، بعد از بf

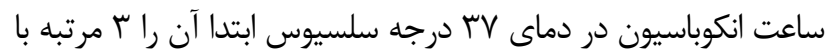
بافر فسفات سالين با ب/ pH V شستشو داده تا باكترىهايى كه به جدار يليت متصل نيستند خارج شوند. سيس با • لم ميكروليتر متانول خالص

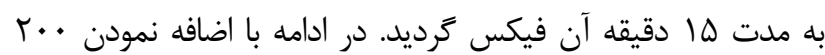
ميكروليتر رنت كريستال ويوله ץ/ به مدت ه دقيقه عمل رنتَآميزى انجام و در ادامه با استفاده از بافر فسفات سالين عمل شستشو صورت

\section{جدول ا. تقسيمبندى باكترىها بر اساس قدرت تشكيل بيوفيلم درروش ميكروتيتريليت}

\begin{tabular}{|c|c|c|}
\hline Mean $\mathrm{OD}$ value & Adherence & Biofilm formation \\
\hline $\mathrm{OD} \leq \mathrm{ODc}$ & None & None \\
\hline $\mathrm{ODc}<\mathrm{OD} \leq 2 \mathrm{ODc}$ & Weak & Weak \\
\hline $2 \mathrm{ODc}<\mathrm{OD} \leq 4 \mathrm{ODc}$ & Moderate & Moderate \\
\hline $4 \mathrm{ODc}<\mathrm{OD}$ & Strong & High \\
\hline
\end{tabular}

ميزان جذب نورى نمونه مورد آزمايش در طولموج • = نانومتر OD

ميانكين ميزان جذب نورى نمونه كنترل منفى در طولموج • Oنانومتر = ODc

شرايط زير بود. دناتوراسيون اوليه

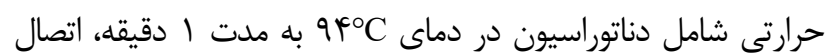
يرايمر در دماى ا دقيقه و تكثير نهايى در دماى VY C

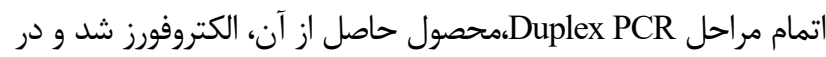
קايان با دستخاه UV ترانس لوميناتور (UV transluminator) مورد ارزيابى قرار گرفت. در انجام آزمايش PCR از آب مقطر باعنوان نمونه كنترل منفى و از سويهى رفرنس/شريشيا كلى كنترل مثبت استفاده شد.

$$
\text { آناليز آمارى }
$$

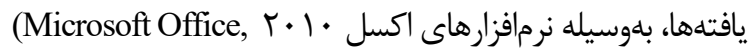
SPSS 2016 (SPSS Inc., ،Microsoft, Washington D.C, USA) ارزيابى شد و از آزمون عدم استقلال در آمار Chicago, IL, USA) استنباطى براى بررسى ارتباط بين متغيرهاى كيفى استفاده شد و

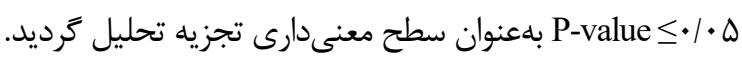

\section{Duplex PCR باكترى جهت استخراج DNA مانجام}

براى استخراج محتواى DNA جدايه هاى باكتريايى از روش جوشاندن استفاده شد (F). يس از استخراج DNA، ارزيابى كيفى و كمى آن با استفاده از اسيكتروفتومتر و الكتروفورز بر روى زل آكاروز ا. انجام شد. DNA استخراجشده تا زمان انجام PCR در •V- درجه سلسيوس نكخدارى شدند.

\section{انجام واكنش Duplex PCR بهمنظور تائيد وجود زنهاى papC و دfa pa جدايه هاى /شريشيا كلى

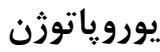
واكنش PCR در حجم نهايى فr ميكروليتر شامل يك ميكروليتر هدف ( DNA

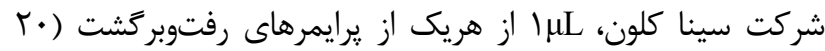
PapC $\quad$ F PapC R و و 9ACGGCTGTACTGCAGGGTGTGGCG-3' sfa F 5' gATATCCTTTCTGCAGGGATGCAATA-3 sfa $\mathrm{R}$ 5- g CTCCGGAGAACTGGGTGCATCTTAC-3 (CGGAGGAGTAATTACAAACCTGGCA-3 مقطر دو بار تقطير و هر برنامه PCR شامل •r جرخه تكثير و تحت 
Kirby - نتايج حاصل تست آنتىبيوگرام با استفاده از روش

يافته ها

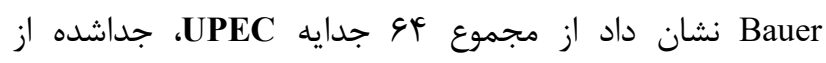

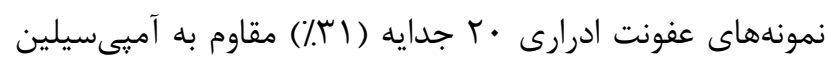
جمع آورى، جداسازى و خالصسازى:

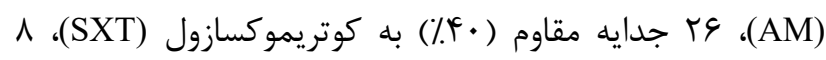

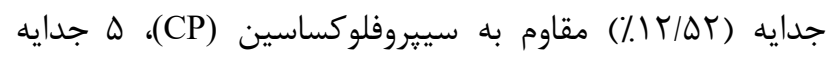
(I/N/N)

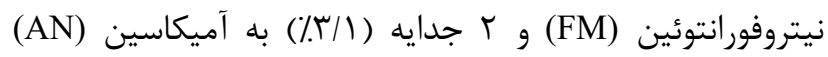
مقاومت بودند (جدول r). نتايج تعيين حساسيت آنتىبيوتيكىى: جدول r. نتايج حاصل از تست تعيين مقاومت آنتى بيوتيكى با روش كربى ـ بائر

\begin{tabular}{|c|c|c|c|}
\hline 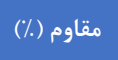 & 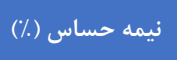 & 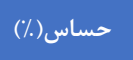 & ديسكهاى آنتىيبوتيك \\
\hline$r \cdot(/, Y / T)$ & $f(1.9 / \Gamma)$ & $r \cdot(/ .9 / / 9)$ & آمبىسيلين •| ميكروكرم (AM) \\
\hline$r \varphi(\varphi \cdot \% / 19)$ & . & $r \wedge(/ \Delta q / \%)$ & كوتريموكسازول \ه ميكروكرم (SXT) \\
\hline$\Lambda(/ .1 Y / \Delta)$ & . & $\Delta g(/ . N V / \Delta)$ & سيبروفلوكساسين ه ميكروكرم (CP) \\
\hline$\Delta(/ / V / \Lambda)$ & $\cdot$ & $\Delta 9(/ 9 T / r)$ & جنتامايسين •ا ميكروكرم (GM) \\
\hline$r(. / . / 9)$ & . & $91(/ 90 / \%)$ & نيتروفورانتوئين •·F ميكروكرم (FM) \\
\hline$r(\mid, r / 1)$ & . & $\operatorname{sr}(1.99 / 9)$ & آميكاسين •r ميكروكرم (AN) \\
\hline
\end{tabular}

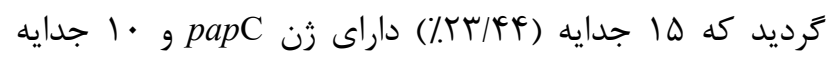

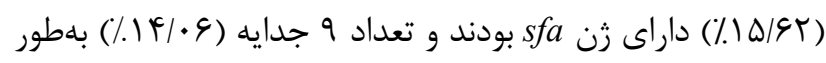

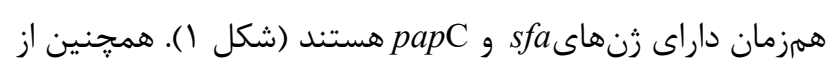

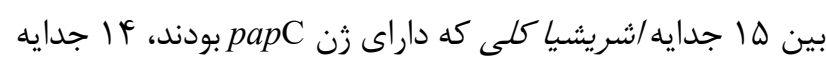

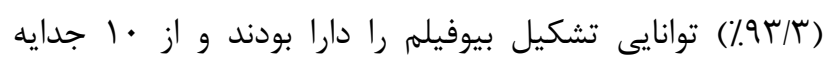

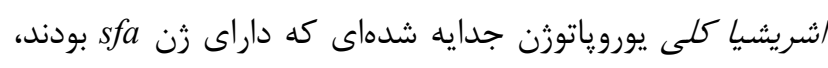

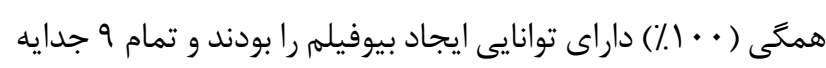

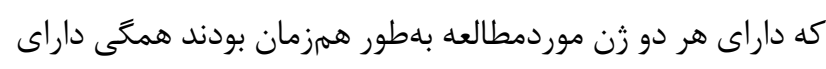

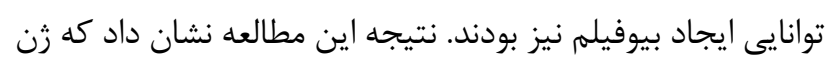
دpapC

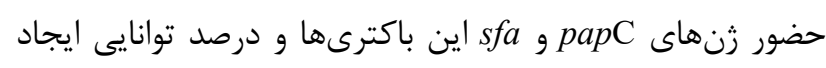

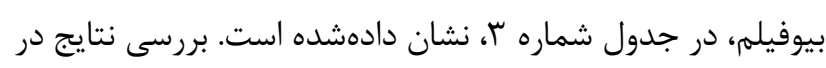

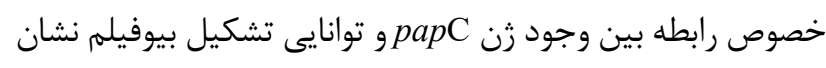

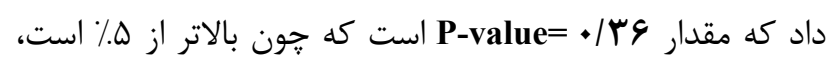

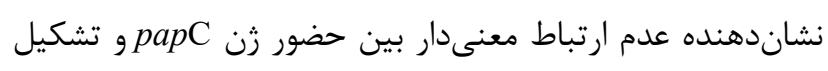

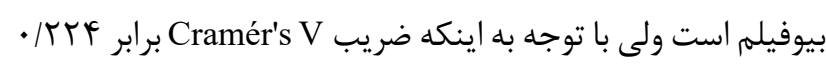

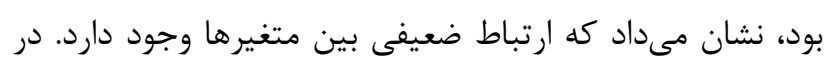

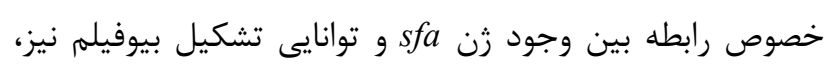

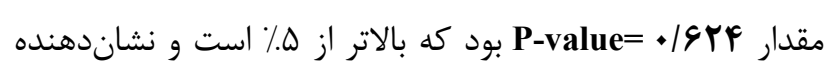

\section{نتايج تست تشكيل بيوفيلم با روش ميكروتيتر يليت:}

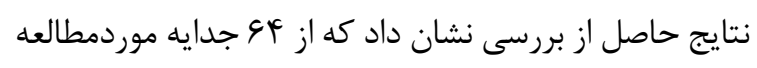

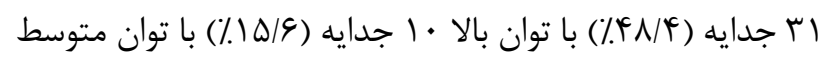

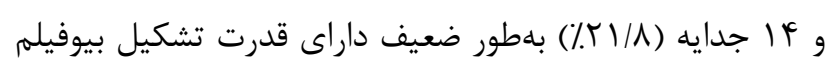

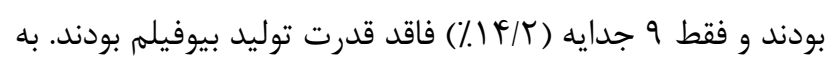

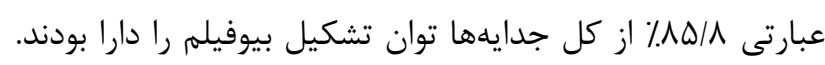

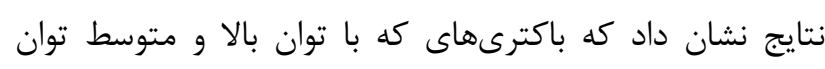

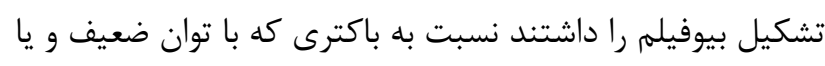

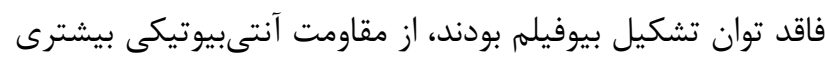

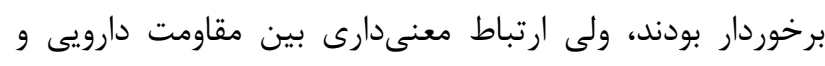
تشكيل بيوفيلم (ه •| • (P ) مشاهده نشد.

\section{نتايج بررسى وجود زنهاى papC و sfa در جدايههاى \\ ا شريشيا كلى يوروياتوزن از Duplex PCR:}

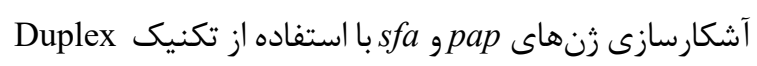
PCR با انجام واكنش Duplex PCR بر روى DNA هاى

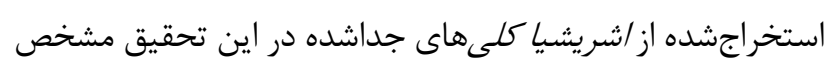




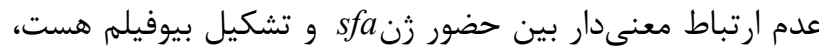

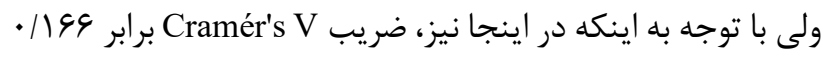
بود، نشان مىداد كه ارتباط ضعيفى بين متغيرها وجود دارد.

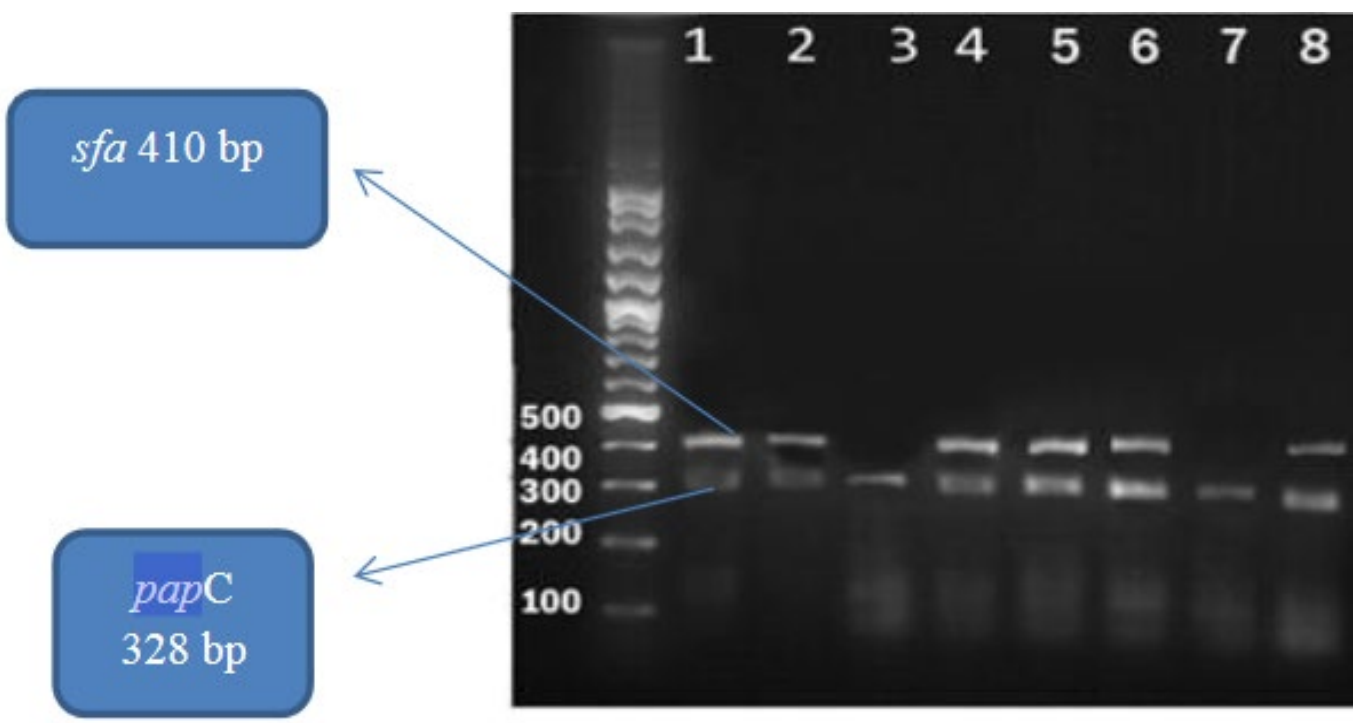

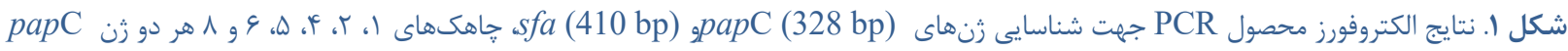

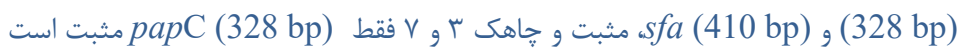

جدول r. نتايج تشكيل بيوفيلمUPEC با روش ميكروتيتريليت و فراوانى زنهاى papC و

\begin{tabular}{|c|cccc|c|}
$\begin{array}{c}\text { Organism and papC, } \\
\text { sfa genes }\end{array}$ & $\begin{array}{c}\text { No of } \\
\text { Isolates }\end{array}$ & $\begin{array}{c}\text { Strong } \\
\text { Biofilm } \\
\text { Formation }\end{array}$ & $\begin{array}{c}\text { Moderate } \\
\text { Biofilm } \\
\text { Formation }\end{array}$ & $\begin{array}{c}\text { Weak } \\
\text { Biofilm } \\
\text { Formation }\end{array}$ & $\begin{array}{c}\text { Negative } \\
\text { Biofilm } \\
\text { Formation }\end{array}$ \\
\hline E. coli & $64(100 \%)$ & $31(48.4 \%)$ & $10(15.6 \%)$ & $14(21.8 \%)$ & $\mathbf{9 ( 1 4 . 2 \% )}$ \\
\hline papC & $15(23.44 \%)$ & $6(9.38 \%)$ & $5(7.81 \%)$ & $3(4.69 \%)$ & $\mathbf{1 ( 1 . 5 6 \% )}$ \\
\hline sfa & $10(15.62 \%)$ & $5(7.81 \%)$ & $2(3.13 \%)$ & $3(4.69 \%)$ & $\mathbf{0}$ \\
\hline papC and $s f a$ & $9(14.06 \%)$ & $5(7.81 \%)$ & $2(3.13 \%)$ & $2(3.13 \%)$ & $\mathbf{0}$ \\
\hline
\end{tabular}

نمىشود (سا). اين باكترى قادر است تجمعات بين سلولى مشابه

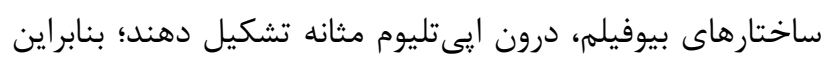

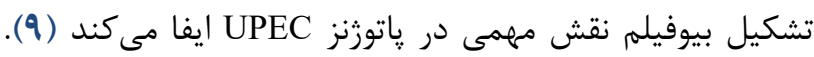
زنهاى pap و sfa شايعترين زنهاى كدكننده يِيلى در /شريشيا

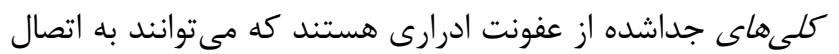

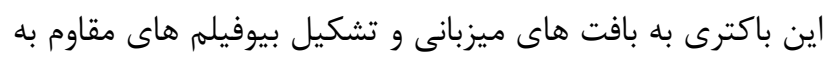
آنتىبيوتيك كمك كنند. شناسايى سويههاى UPEC توليد

\section{بحث}

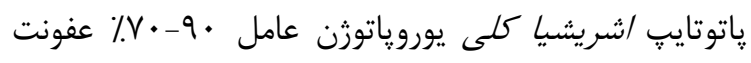

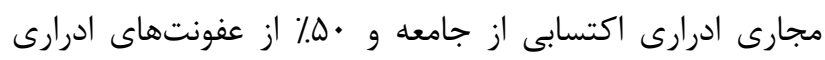

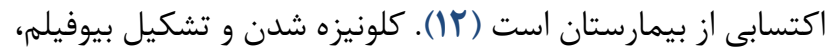
اشريشيا كلى يوروياتوزن در ابیىتليوم مخاطى به بافت ميزبان

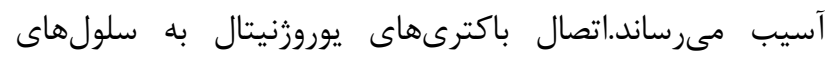

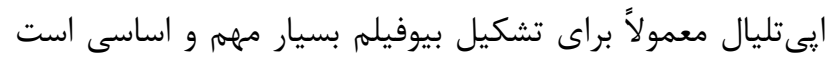

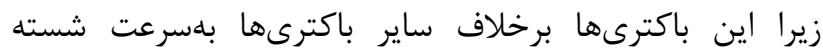


اشريشيا كلىهاى جداشده از نمونههاى ادرارى را نسبت به

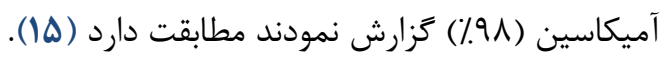
همجنين در تحقيقى كه توسط Milani و همكاران، در طى

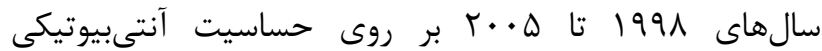
باكترىهاى جداشده از افراد مبتلابه UTI انجام شد، بيشترين

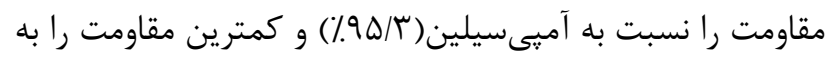

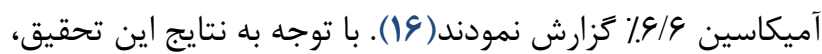
ميزان مقاومت به آميىسيلين نسبت به يافتههاى ما بيشتر بوده است ولى در مطالعه ما نيز اغلب جدايهها نسبت به آميكاسين حساسيت نشان دادند.

نتايج مطالعه حاضر نشان داد، بيش از آ I أز جدايهها به بيش از دو گروه آنتىبيوتيكها موردمطالعه مقاوم بودند. در

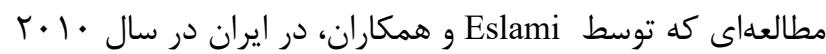

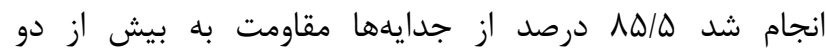
آنتىبيوتيك را نشان دادند (IV). در مطالعه Molina_Lopez و

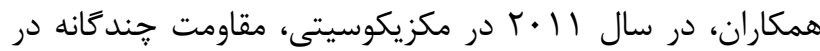
سويdهاى UPEC نتايج مشابهى را نشان مى داد (11). در اين مطالعه كمترين مقاومت نسبت به آميكاسين و نيتروفورانتوئين بود كه مشابه مطالعات Molina_Lopez و همكاران، در سال || • ب است (1) (1). در مطالعهى Mansouri و همكاران، ميزان مقاومت به

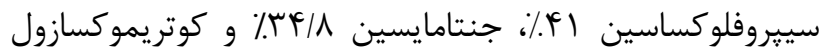
1/1/\% بود كه در مقايسه بامطالعه حاضر از مقاومت بالاترى برخوردار است (19)؛ كه اين مىتواند به علت تفاوت مناطق جغرافيايى و منابعى باشد كه باكترى از آنها جداشده است. يكى از عواملى كه در پاتوزنز و همجنين در مقاومت به عوامل ضد ميكروبى نقش ايفاء مى كند قدرت تشكيل بيوفيلم است.

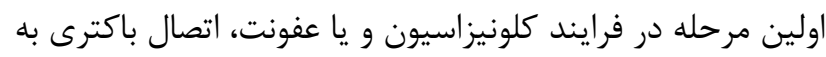

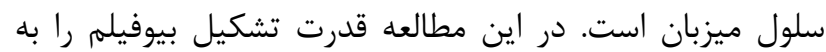
روش ميكروتيتريليت كه يك روش كيفى استاندارد محسوب مىشود موردبررسى قرار زرفت (F).

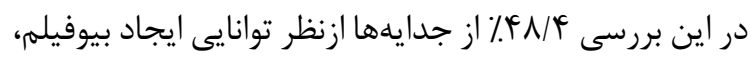

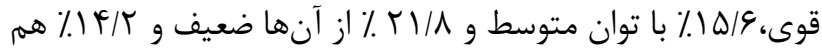
فاقد توانايى تشكيل بيوفيلم بودند. در مطالعه Sevanan و همكاران، در سال Iا • ب، از روش تشكيل بيوفيلم در لوله (Tube Method)

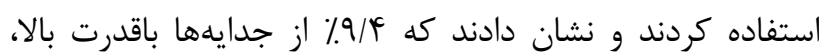

بيوفيلم براى درك بهتر بيمارىزايى و مقاومت آنتىبيوتيكى اين باكترى در ايجاد عفونت ادرارى حائز اهميت است. از طرفى تعيين الكوى مقاومت آنتىبيوتيكى /شريشيا كلى در جدايه هاى عفونت ادرارى در سطح كشور در راستاى شناخت داروهاى مؤثر در درمان اوليه عفونتهاى ادرارى و ايجاد مقاومتهاى نوظهور در اين ياتوزن شايع عفونت ادرارى، مىتواند در كنترل عفونتهاى ادرارى بالهميت باشد. اگرجه در مناطق مختلف ايران بر روى سويههاى اشريشيا كلى جدا سده از عفونت ادرارى مطالعاتى انجامشده است

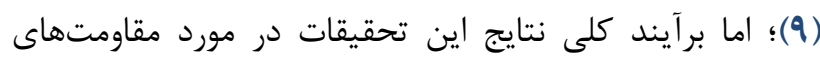
شاخص و فراخير و يا مقاومتهاى نوظهور اشريشيا كلى در سطح كشور در دسترس نيست. همجنين روند تغيير الگوى حساسيت آنتىبيوتيكى اين پاتوزن اصلى دستخاه ادرارى در سطح كشور مشخص نيست.

بنابراين با توجه به مطالب ذكرشده اين تحقيق با اهداف، تعيين ميزان مقاومت آنتىبيوتيكى در /شريشيا كلى عامل عفونتهاى مجارى ادرارى، بررسى قدرت تشكيل بيوفيلم/شريشيا كلى يوروياتوزنيك به روش فنوتييى و بررسى فراوانى زنهاى فيمبريه اى pap و sfa با استفاده روش Duplex PCR، ارتباط بين آنها و بر روى · • ا نمونهى ادرار جمعآورىشده از خانمهاى باردار

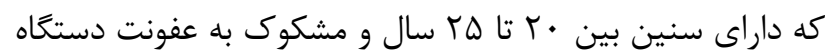

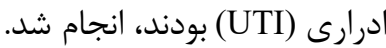

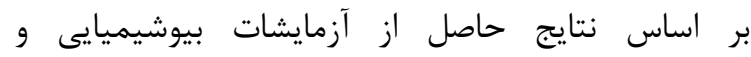

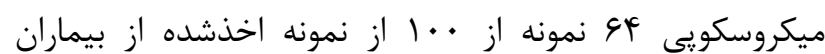

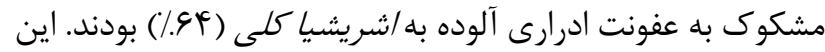

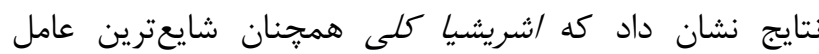
عفونتهاى ادرارى است. در اين مطالعه مقاومت باكترى UPEC مسبب عفونت ادرارى نسبت به آنتىبيوتيكها موردبررسى قرار گرفت. بر اساس نتايج؛ بيشترين ميزان مقاومت به ترتيب مربوط به كوتريموكسازول

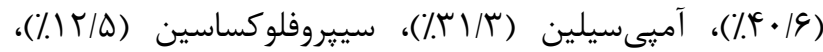

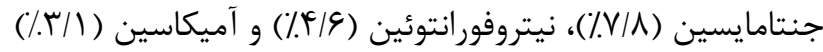
بود، كه با نتايج مطالعهاى كه توسط Mattai و همكاران، در سال

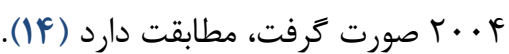
اشريشياكلىهاى جداشده در اين بررسى، بيشترين

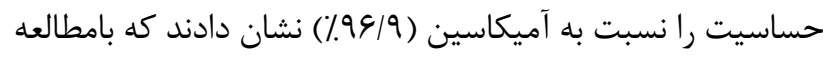
Abdollahi Kheirabadi 


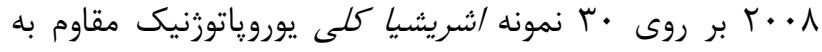
فلوروكينولونها در نروز مشخص شد كه فراوانى زنهاى sfa pap

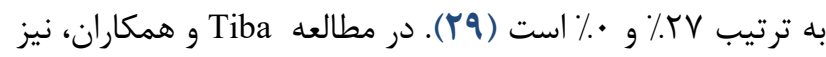

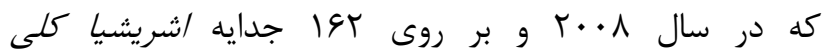
يوروياتوزنيك در برزيل انجام شد، فراوانى زنهاى sfa afa ، و

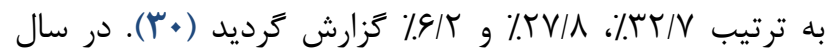

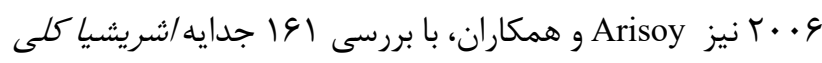

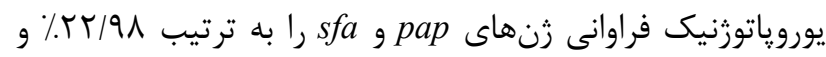

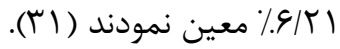

در مطالعه ديكر كه توسط Fathollahi و همكاران، بر روى

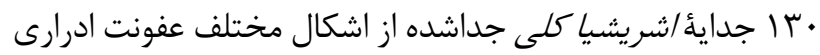

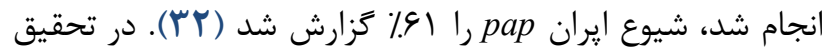
Karimian

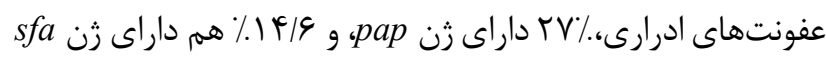

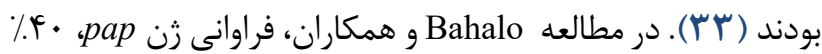

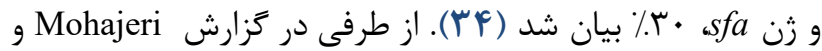

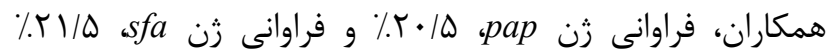

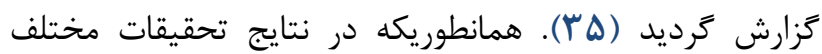

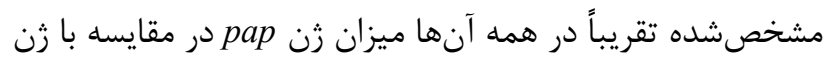

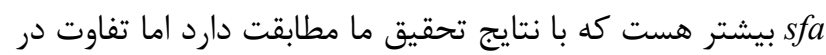
درصدهاى ذكرشده نيز وجود دارد كه ممكن است به دليل تفاوت

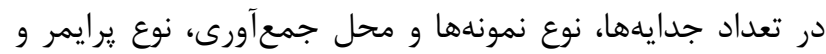

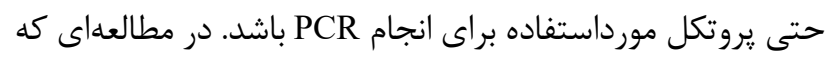
در سال 11 إr توسط Zamani و همكاران كه بر روى UPEC

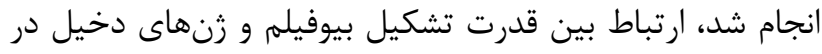

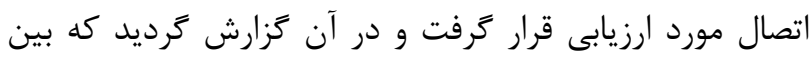
sfaS

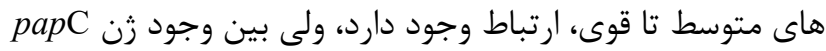

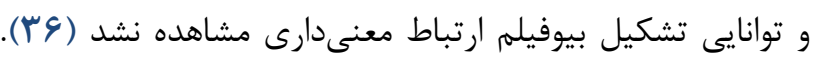

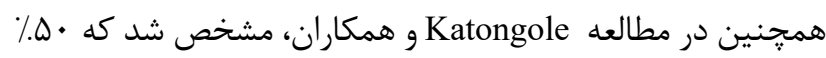
از جدايه هاى حاوى ثن papC توانايى تشكيل بيوفيلم رادارند ولى همانى

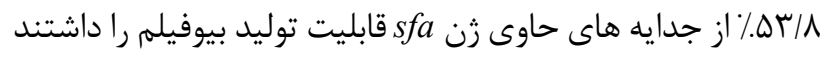

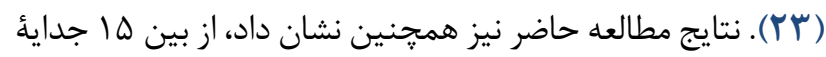

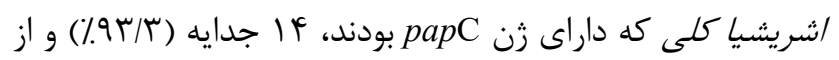

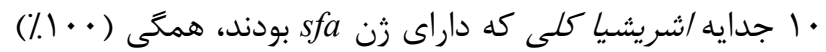

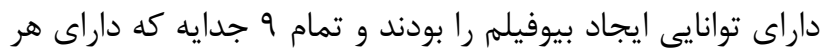
دو زن موردمطالعه بهطور همزمان بودند همعَى داراى توانايى ايجاد

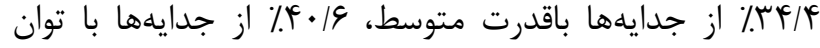

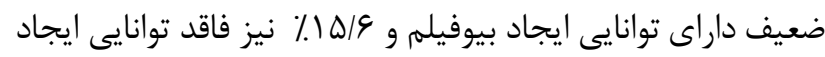

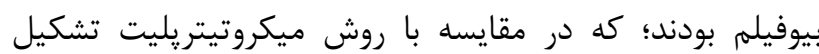
بيوفيلم بيشترى را نشان دادند (•r). همجنين -Rawa'a Al Chalabi سويههاى/شريشيا كلى يوروياتوزن توانايى تشكيل بيوفيلم رادارند

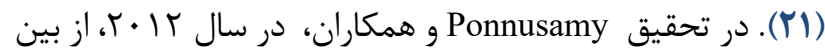

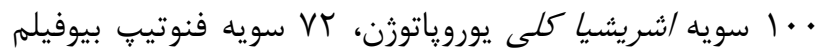

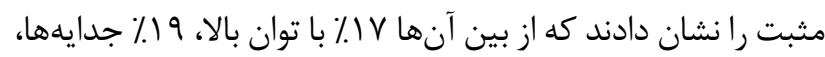

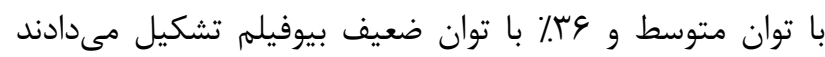

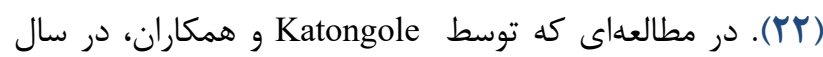

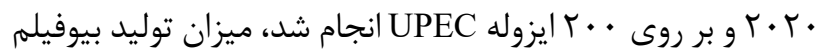

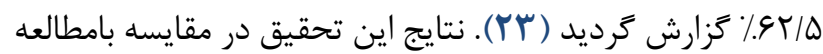

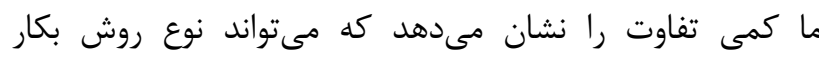

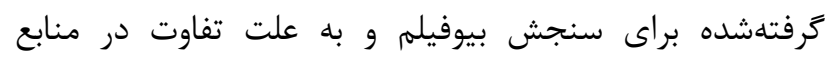
جداسازى نمونهها باشد.

در اين مطالعه از روش Duplex PCR، براى بررسى حضور

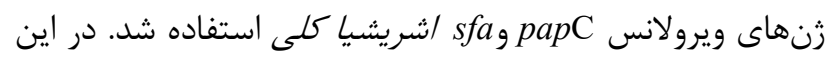

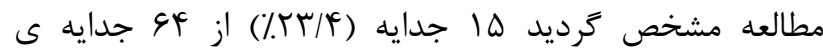

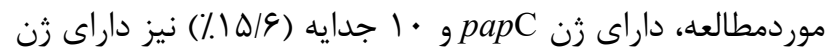

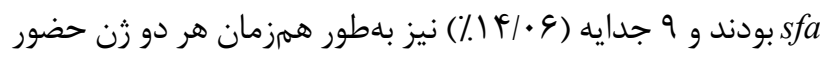

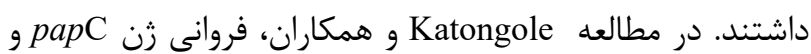

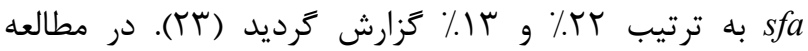
Tarchouna

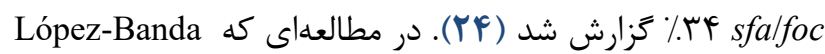

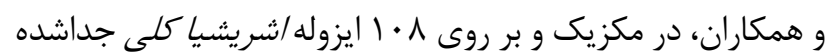

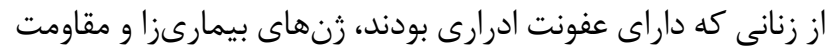

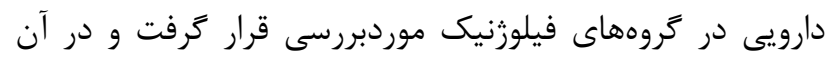

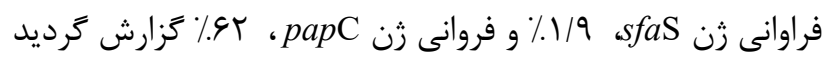

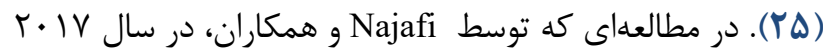
در شهر بوشهر ايران و بر روى • f أ جدايه UPEC انجام شد، ميزان

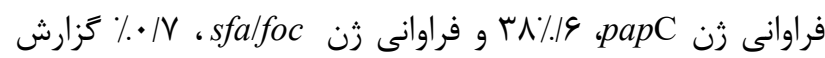

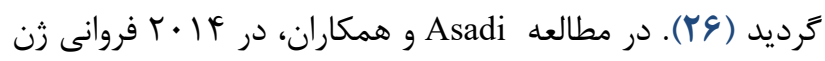

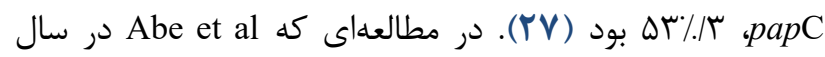

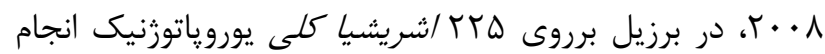

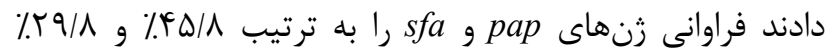

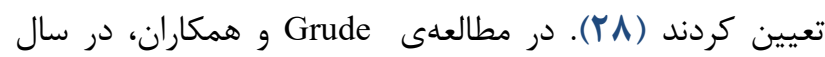


دارا هست. از طرفى توانايى ايجاد بيوفيلم در .1٪ از جدايههاى

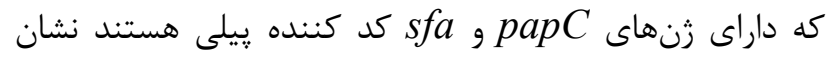

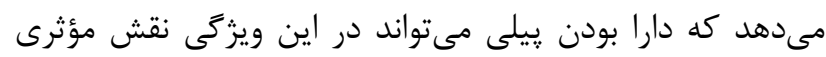
داشته باشد. نتايج همجنين، نشان داد كه ارتباط مستقيمى بـ دين قدرت تشكيل بيوفيلم و افزايش مقاومت دارويى در باكترى UPEC اشريشيا كلى در جدايههاى بهدستآمده از عفونتهاى ادرارى در سطح كشور، در شناخت داروهاى مؤثر در درمان اوليه عفونتهاى ادرارى و كنترل عفونتهاى ادرارى بسيار، باهميت است.

$$
\text { سياسگزارى }
$$

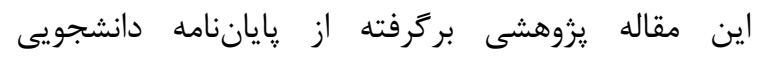
كارشناسى ارشد ميكروبيولوزى است. نويسندكان اين مقاله از ازئ رياست محترم دانشكده علوم و كارشناسان محترم آزمايشكاه تحقيقاتى ميكروبشناسى دانشعاه آزاد اسلامى واحد كرج نهان داشترمايت تشكر و قدردانى رادارند.

$$
\text { تعارض در منافع }
$$

بين نويسندگان مقاله هيجّ گونه تعارض منافعى وجود ندارد همه نويسندكان نسخه نهايى خطى را تأييد كردند.

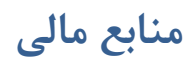
اين تحقيق با هزينه شخصى و با كمك و مساعدت دانشعاه آزاد

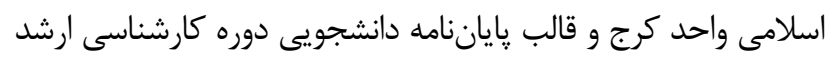

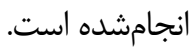

بيوفيلم بودند. اكرجه، اين نتايج نشاندهنده نقش اين رنها در

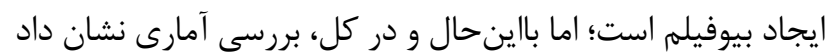

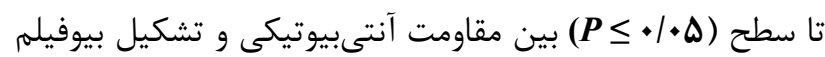

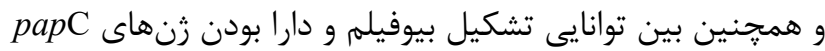

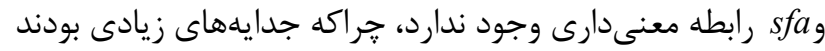

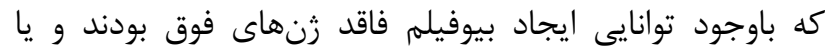
باوجوداينكه مقاومت آنتىبيوتيكى در بين جدايىهايى بئى كه داراى توانايى بيوفيله، بيشتر بود، ولى تعداد قابلتوجهى هم باوجود

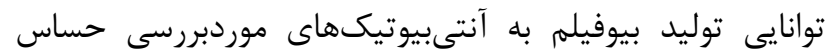

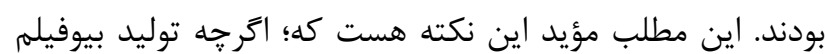
سبب افزايش مقاومت آنتىبيوتيكى در باكترىها مىشود، ولى مقاومت دارويى فقط به وجود بيوفيلم بستخى ندارد و عوامل متعدد

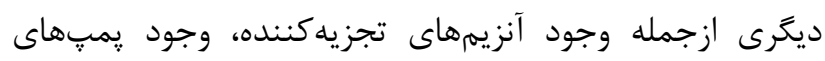
افلاكس، تغييرات در جايخاه اثر و غيره در ايجاد مقاومت نقش دارئرد و همجنين اكرجه زنهاى كد كننده پيلى در ايجاد بيوفيلم مؤثر است ولى علاوه بر ييلى عوامل متعدد ديخرى در باكترى ها (ازجمله وجود كيسول و يروتئينهاى سطحى و...) در ايجاد بيوفيلم موثراند

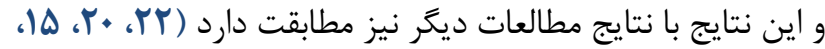

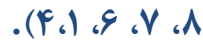
نتيجه گيرى بر اساس نتايج حاصل از اين مطالعه UPEC هم: ليجنان

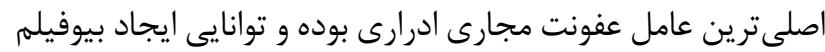

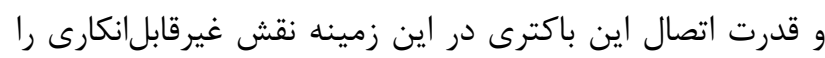

\section{Referance}

1. Johanson I, Lindstedt R, Svanborg C. Roles of the pap and prs encoded adhesins in Escherichia coli adherence to human uroepithelial cells. Infect Immun.1992; 60:

3416-22. [DOI:10.1128/IAI.60.8.3416-3422.1992] [PMID] [PMCID]

2. Johnson D E, Lockatell C V, Russell R G, Hebel J R, Island M D, Stapleton A and et al. Comparison of Escherichia coli strains recovered from human cystitis and pyelonephritis infections in transurethrally challenged mice. Infect. Immun.1998; 66: 3059-65. [DOI: 10.1128/IAI.66.7.3059-3065.1998] [PMID] [PMCID]

3. Marrs CF. Escherichia coli mediated urinary tract infections: are there distinct uropathogenic E. coli
(UPEC) pathotypes? FEMS Microbiol. Lett.2005; 18:190-252.

\section{[DOI:10.1016/j,femsle.2005.08.028] [PMID]}

4. Babapour E, Haddadi A, Mirnejad R, Angaji S A, and Amirmozafari N. Biofilm formation in clinical isolates of nosocomial Acinetobacter baumannii and its relationship with multidrug resistance. Asian Pac J Trop Biomed. 2016; 6(6): 528-533. [DOI: 10.1016/j.apjtb.2016.04.006]

5. Hanna A, Berg M, Stout V, Razatos A. Role of capsular colanic acid in adhesion of uropathogenic Escherichia coli. Applied Environmental Microbiology. 2003; 69(8): 4474-81. [DOI:10.1128/AEM.69.8.4474-4481.2003] [PMID] [PMCID] 
6. Lane MC, Mobley H. Role of P-fimbrial-mediated adherence in pyelonephritis and persistence of uropathogenic Escherichia coli (UPEC) in the mammalian kidney. Kidney. 2007; 72: 19-25. [DOI:10.1038/sj.ki.5002230] [PMID]

7. Usein CR, Damian M, Tatu-Chitoiu D, Capusa C, Fagaras R, Tudorache D, Nica M, Le Bouguénec C. Prevalence of virulence genes in Escherichia coli strains isolated from Romanian adult urinary tract infection cases. J Cell Mol Med. 2001 Jul-Sep; 5(3):303-10. [DOI:10.1111/j.15824934.2001.tb00164.x] [PMID] [PMCID]

8. Schwartz DJ, Conover MS, Hannan TJ, Hultgren SJ. Uropathogenic Escherichia coli superinfection enhances the severity of mouse bladder infection. PLoS Pathog. 2015 Jan 8; 11(1):e1004599. [DOI:10.1371/journal.ppat. 1004599] [PMID] [PMCID]

9. Abe CM, Salvador FA, Falsetti IN, Vieira MA, Blanco J, Blanco JE, Blanco M, Machado AM, Elias WP, Hernandes RT, Gomes TA. Uropathogenic Escherichia coli (UPEC) strains may carry virulence properties of diarrhoeagenic E. coli. FEMS Immunol Med Microbiol. 2008 Apr; 52(3):397-406. [DOI:10.1111/j.1574-695X.2008.00388.x] [PMID]

10. CLSI. Performance Standards for Antimicrobial Susceptibility Testing. 27th ed. CLSI supplement M100. Wayne, PA: Clinical and Laboratory Standards Institute; 2017.

11. Tajbakhsh E, Ahmadi P, Abedpour-Dehkordi E, Arbab-Soleimani N, Khamesipour F. Biofilm formation, antimicrobial susceptibility, serogroups and virulence genes of uropathogenic E. coli isolated from clinical samples in Iran. Antimicrob Resist Infect Control. 2016 Apr 1;5:11. [DOI: 10.1186/s13756-016-0109-4] [PMID] [PMCID]

12. Daigle F, Harel J, Fairbrother J M, Lebel P. Expression and detection of pap, sfa, and afaencoded fimbrial adhesin systems among uropathogenic Escherichia coli.Clin.J Microbial.1994; 40: 286-91. [DOI:10.1139/m94046] [PMID]

13. Mansouri M, Abbasi S. Prevalence of multiple drugresistant clinical isolates of extended-spectrum betalactamase-producing Enterobacteriaceae in southeast Iran. IJMS.2010; 35(2): 101-108.

14. Mathai E, Chandy S, Thomas K, Antoniswamy B, Joseph I, Mathai M, Sorensen TL, Holloway K. Antimicrobial resistance surveillance among commensal Escherichia coli in rural and urban areas in Southern India. Trop Med Int Health. 2008 Jan;
$13(1): 41-5$ 3156.2007.01969.x] [PMID]

15. Abdollahi Kheirabadi S, Najafipour S, Kafilzadeh F, Abdollahi A, Jafari S, Moravej A. Evaluation of Drug Resistance Pattern of Escherichia coli Strains Isolated from Fasa Vali-e-Asr Hospital Patients. J Fasa Univ Med Sci. 2013; 2(4): 273-278.

16. Milani M, Nahaei M R, Lotfipour F, Yousefee S. Antibiotic sensitivity of prevalent Bacteria isolated from urinary tract infection during 1998-2005. Pharm Sci. 2008; 4: 47-53.

17. Eslami G, Seyedjavadi S S, Goudarzi H, Fallah F, Goudarzi M. Distribution of Integrons among Multidrug-Resistant E. coli and Klebsiella Strains. J Res Med Sci. 2010; 34 (1):61-65. URL: http://pejouhesh.sbmu.ac.ir/article-1-737-fa.html.

18. Molina-López J, Aparicio-Ozores G, Ribas-Aparicio RM, Gavilanes-Parra S, Chávez-Berrocal ME, Hernández-Castro R, Manjarrez-Hernández HÁ. Drug resistance, serotypes, and phylogenetic groups among uropathogenic Escherichia coli including O25-ST131 in Mexico City. J Infect Dev Ctries. 2011 Dec 13;5(12):840-9. [DOI: 10.3855/jidc.1703] [PMID]

19. Mansouri M, Abbasi S. Prevalence of multiple drugresistant clinical isolates of extended-spectrum betalactamase-producing Enterobacteriaceae in southeast Iran. IJMS.2010; 35(2): 101-108

20. Sevanan Murugan, Pongiya Uma Devi and Peedikayil Neetu. Antimicrobial Susceptibility Pattern of Biofilm Producing Escherichia coli of Urinary Tract Infections. Microbiol Curr Res. 2011; 4: 73-80. [DOI:10.3923/crb.2011.73.80]

21. Al-Ubaidy A, Al-Ibadi M. Detection of Urovirulence Genes (eae, E-hly, $\alpha$-hly) of Uropathogenic Escherichia coli by Specific PCR. JoBRC. 2010; 4(1): 44-54.

22. Ponnusamy $\mathrm{P}$, Natarajan V, Sevanan M. In vitro biofilm formation by uropathogenic Escherichia coli and their antimicrobial susceptibility pattern. Asian Pac J Trop Med. 2012 Mar; 5(3):210-3. [DOI:10.1016/S1995-7645(12)60026-1]

23. Katongole P, Nalubega F, Florence N C, et al. Biofilm formation, antimicrobial susceptibility and virulence genes of Uropathogenic Escherichia coli isolated from clinical isolates in Uganda. BMC Infect Dis. 2020; 20: 453. [DOI:10.1186/s12879020-05186-1] [PMID] [PMCID]

24. Tarchouna M, Ferjani A, Ben-Selma W, Boukadida J. Distribution of uropathogenic virulence genes in Escherichia coli isolated from patients with urinary tract infection. IJID. 2013; 17(6): 450-453. [DOI:10.1016/j.ijid.2013.01.025] [PMID] 
25. López-Banda D A, Carrillo-Casas E M, LeyvaLeyva M, Orozco-Hoyuela G, Manjarrez-Hernández Ál H, Arroyo-Escalante S, et al. Identification of Virulence Factors Genes in Escherichia coli Isolates from Women with Urinary Tract Infection in Mexico. Biomed Res Int. 2014; 2014: Article ID 959206, 10 pages. [DOI:10.1155/2014/959206] [PMID] [PMCID]

26. Najafi A, Hasanpour M, Askary A, Aziemzadeh M, Hashemi N. Distribution of pathogenicity island markers and virulence factors in new phylogenetic groups of uropathogenic Escherichia coli isolates. Folia Microbiol (Praha). 2018 May;63(3):335-343. [DOI: 10.1007/s12223-017-0570-3] [PMID]

27. Asadi S, Kargar M, Solhjoo K, Najafi A, GhorbaniDalini S. The Association of Virulence Determinants of Uropathogenic Escherichia coli With Antibiotic Resistance. Jundishapur J Microbiol. 2014 May;7(5):e9936. doi: 10.5812/jjm.9936. Epub 2014 May 1. [DOI:10.5812/ijm.9936] [PMID] [PMCID]

28. Abe CM, Salvador FA, Falsetti IN, Vieira MA, Blanco J, Blanco JE, et al. Uropathogenic Escherichia coli (UPEC) strains may carry virulence properties of diarrhoeagenic E. coli. FEMS Immunol Med Microbiol. 2008 Apr;52(3):397-406. [DOI:10.1111/j.1574-695X.2008.00388.x] [PMID]

29. Grude N, Srand L, Mykland H, Nowrouzian FL, Nyhus J, Jenkins A, et al. Fluoroquinolone resistant Uropathogenic Escherichia coli in Norway: evidence of clonal spread. Clin microbial and Infect2008; 14(5): $\quad 498-500 . \quad$ [DOI:10.1111/j.14690691.2008.01952.x] [PMID]

30. Tiba MR, Yano T, Leite DDS. Genotypic characterization of virulence factors in Escherichia coli strains from patients with cystitis. Rev Inst Med Trop. 2008; 50(5)255-60. [DOI:10.1590/S003646652008000500001] [PMID]

31. Arisoy M, Ayser D, Ekim M, Ozel D, Kose S K, Ozsoy E D, et al. Detection of virulence factors of E.coli from children by Duplex PCR. Int J Clin Pract. 2005; 60: 170-73. [DOI:10.1111/j.17421241.2005.00668.x] [PMID]

32. Fathollahi S, Yousefi-Mashouf R, Taghi Goodazi M, Hajilooe M, Hemati S, Mostafaei A, et al. Typing of the uropathogenic E.coli strains using O-serotyping and detection of pap adhesion-encoding operon by a polymerase chain reaction. Iranian Journal of Clinical Infectious Diseases. 2009; 4(2): 77-81.

33. karimian A, Momtaz H, Madani M. Detection of uropathogenic Escherichia coli virulence factors in patients with urinary tract infections in Iran. African J Microbiol. Res. 2012; 6(39):6811-6816. [DOI:10.5897/AJMR12.1462]
34. Bahalo S, Tajbakhsh E, Tajbakhsh S, Momeni M, Tajbakhsh F. Detection of some virulence factors of Escherichia coli isolated from urinary tract infection isolated of children in Shahrekord Iran by Multiplex PCR. Middle-East J Scien Res. 2013;14(1):29-32.

35. Mohajeri P, Khademi H, Ebrahimi R, Farahani A, Rezaei M. Frequency distribution of virulence factors in uropathogenic Escherichia coli isolated from Kermanshah in 2011-2012. Int J Appl Basic Med Res. 2014; 4(2):111-6. [DOI:10.4103/2229516X.136794] [PMID] [PMCID]

36. Zamani H, Salehzadeh A. Biofilm formation in uropathogenic Escherichia coli: association with adhesion factor genes. Turk J Med Sci. 2018 Feb 23;48(1):162-167. [DOI:10.3906/sag-1707-3] [PMID] 